\begin{tabular}{|c|l|}
\hline Title & Family labor supply, commuting time, and residential decisions: The case of the Tokyo Metropolitan A rea \\
\hline Author(s) & A be, Yukiko \\
\hline Citation & $\begin{array}{l}\text { Journal of Housing Economics, 20(1), 49-63 } \\
\text { https://doi.org/10.1016/.jhe.2010.12.001 }\end{array}$ \\
\hline Issue Date & 2011-01 \\
\hline Doc URL & http://hdl.handle.net/2115/58503 \\
\hline Type & article(author version) \\
\hline File Information & abe_commmute_huscap.pdf \\
\hline
\end{tabular}

Instructions for use 


\title{
Family labor supply, commuting time, and residential decisions: the case of the Tokyo Metropolitan Area *
}

\author{
Yukiko $\mathrm{Abe}^{\dagger}$
}

August 1, 2010

\begin{abstract}
In this paper, I build a model of family labor supply and residential choices that explicitly incorporates the full-time or part-time work decisions of married women. The model can explain why women's participation patterns in full-time and part-time work vary significantly in areas that are geographically close but differ in real estate prices. The model suggests that high commuting costs could be one of the main obstacles for women's full-time employment in places like the Tokyo Metropolitan Area.

JEL classification: J22, R21, R23

Key words: Commuting, family labor supply, part-time work
\end{abstract}

${ }^{*}$ This paper uses microdata of the Employment Status Survey (ESS) made available through the Ministry of Internal Affairs and Communication of Japan. Microdata cannot be released due to the terms of usage of the data. I thank Kazuyasu Sakamoto, Yasuhiro Sato, and seminar participants at Nagoya University and Toyama University for helpful comments. This paper was presented at the 2009 Spring Meeting of the Japanese Economic Association at Kyoto University (June 6, 2009) and FESAMES 2009 Meeting at University of Tokyo (August 3, 2009). Remaining errors are my own. This research is supported by the Japan Society for Promotion of Science Grant-in-Aid for Scientific Research (Grant Number B-19330053 and C-20530188).

${ }^{\dagger}$ Corresponding Author. Graduate School of Economics and Business Administration, Hokkaido University, Kita 9 Nishi 7, Kita-ku, Sapporo, 060-0809 JAPAN. Phone: +81-11706-3860, Fax: +81-11-706-4947, E-mail: abey@econ.hokudai.ac.jp 


\section{Introduction}

How is women's employment related to the geographical distribution of households? The present paper explores this question in a specific context: the Tokyo Metropolitan Area in Japan. I present an optimizing model of family labor supply and residential choices that incorporates an important institutional feature of the Japanese labor market: the decision by women to work full time or part time. The Tokyo Metropolitan Area is also unique in that real estate prices are much higher for locations close to the Central Business District $(\mathrm{CBD})$.

Costa and Kahn (2000) show that highly educated "power couples" in the United States became more likely to locate in the Metropolitan Statistical Areas (MSAs) from 1940 to 1990. They attribute this change to the colocation problem, i.e., the difficulty of finding a residence convenient to both spouses' workplaces. In contrast, Compton and Pollak (2007) analyze panel data and show that power couples are no more likely than other types to migrate to large metropolitan areas. Accordingly, they argue that colocation is not a major cause of the concentration of power couples in large MSAs. ${ }^{1}$ Neither of these studies, however, is very explicit about the relationship between residential decisions and housing prices.

Several studies have investigated the relationship between women's employment and housing purchases. Yoshikawa and Ohtake (1989), Fortin

\footnotetext{
${ }^{1}$ Compton and Pollak (2007) also show that the concentration of power couples in MSAs declined slightly between 1990 and 2000.
} 
(1995), and Del Boca and Lusardi (2003) empirically examine how the working status of married women is related to housing purchases by their households. In the regional science literature, Mok (2007) asks whether incomes of spouses are pooled or not in deciding housing location. Using the Canadian Census data for the Toronto Metropolitan Area, she finds that incomes are not pooled for couples without children. Iwata and Tamada (2008) build a model of commuting behavior of married women and argue for a nonmonotonic relationship between the wage rate of working married women and their commuting time. Sakanishi $(2007,2008)$ builds a model in which household location is determined by the husband's choice and the wife chooses her employment status given the husband's location.

In this paper I present a model of family labor supply that permits married women to choose from full-time and part-time job opportunities. The commuting costs, wage levels, and working hours for the two employment options are explicitly modeled so as to reflect the real constraints faced by couples in Japan. The model explains why the distribution of women's employment status differs significantly across prefectures in the Tokyo Metropolitan Area. Although the theoretical model is constructed to explain the facts for the Tokyo Metropolitan Area, the implications of the model are broadly consistent with empirical patterns observed in the New York Metropolitan Area: evidence from the New York area is reported in the Appendix.

The paper makes two novel contributions to the literature. First, it explicitly considers the optimization over married women's work (either full-time 
or part-time) and residential location. In modeling this, the "discreteness" of these two choices is particularly emphasized. This element of the model is especially relevant in the Tokyo Metropolitan Area, where full-time work is more common among women living close to the CBD than among women living in the suburbs. Such regional differences in participation are not observed for men (Section 2). By modeling the family's housing location and labor supply decisions simultaneously, this model provides a natural explanation for such patterns.

Second, the paper highlights the importance of commuting costs in understanding women's work in Japan. Several important measures (legal and otherwise) to promote women's participation in the workplace have been adopted in Japan in recent decades (e.g., the Equal Employment Opportunity Law, the Maternity Leave Law, and various policies to make balancing work and family easier). Nonetheless, the proportion of women working in regular full-time jobs in Japan has not increased much, especially over age 40. Most of the increase in women's employment after middle age has taken the form of non-regular, part-time work (Abe 2010). Commuting costs (including the time and energy necessary for commuting) have not fallen much for female workers in the past several decades, which may explain the sluggish increase in regular full-time employment for women.

The unique aspect of the model is that it explicitly incorporates the discreteness of the labor market in terms of full- or part-time status. In Japan, full-time wages are much higher than part-time wages. Furthermore, it is 
difficult for women who left the labor force at childbearing age to return to regular employment (Ueda 2007). These factors make full-time and part-time work very distinct, whereas the middle ground between these two options is almost nonexistent. The model shows that the housing market operates in a way to further strengthen this discrete feature in the labor market.

Discreteness in the labor market can sometimes be mitigated by other "markets." For instance, if annual full-time earnings are higher than parttime earnings, in a multi-period setting full-time workers retire early but parttime workers retire late. Then lifetime earnings from the two employment statuses are more equalized than for single-period earnings, implying that intertemporal substitution mitigates discreteness in a single period. ${ }^{2}$ What is unique about the housing market in this paper is that it operates to magnify the discreteness in the labor market.

The property whereby high-wage workers live close to the CBD whereas low-wage workers live farther from the CBD is common in many monocentric models because the bid-rent gradient is higher for high-wage earners. By contrast, the model in this paper assumes that all men work at CBD while women have the option to engage in part-time employment for which the commuting time is zero. In this model, the distance from the CBD creates larger differences on women's behavior than for men's. The large discrepancy in women's behavior is caused by the discreteness in the labor market,

\footnotetext{
${ }^{2}$ Abe (2009), albeit in a different setting from this paper, presents a model that explains this point.
} 
magnified by the housing market.

The remainder of the paper is organized as follows. Section 2 presents stylized facts on regional differences in labor market participation. Section 3 presents a model that explains the stylized facts. Section 4 provides numerical examples of the model and Section 5 concludes. The Appendix reports evidence from the New York Metropolitan Area.

\section{Stylized Facts}

\subsection{Discreteness in women's employment choices: full- time and part-time work in the Japanese labor market}

To introduce the stylized facts to be explained in the theoretical model, I begin with an overview of full-time and part-time work in the Japanese labor market. In subsections 2.1 and 2.2, participation in the two types of wagesalary earners is considered: (1) regular full-time employees and (2) part-time and casual employees. ${ }^{3}$ Part-time and casual employees comprise the typical non-regular workforce in Japan and their numbers have increased dramat-

\footnotetext{
${ }^{3}$ In the data used in this paper, part-time and casual are the terms for employment status in the workplace. Both part-time and casual employees are non-regular workers. There is no clear distinction in tasks or working conditions for the two types of workers, although casual workers are generally younger than part-time workers. Students who work part time normally work under casual status. In the questionnaire of the Employment Status Survey (ESS, Statistics Bureau, Ministry of Internal Affairs and Communications of Japan), casual workers are referred to as "arbeit workers."
} 
ically in recent decades. According to the ESS, among women aged 25-59 years, the number of part-time or casual workers was 4.5 million in 1987 and 7.4 million in $2007 .{ }^{4}$ Regular employees are those with no term limits in their employment contracts. Part-time and casual employees typically hold a contract of no longer than 1 year in duration, although such contracts are often renewed multiple times. Regular employees are eligible for employer-provided fringe benefits, including public pension contributions, a corporate pension, and employer-provided health insurance; part-time and casual employees are much less likely to obtain such coverage. Regular employees normally work 40 hours per week or more, whereas part-time and casual employees work fewer hours. Hourly wage rates are higher for regular employees than for part-time employees; according to the statistics reported in Abe and Tanaka (2007), the part-time/full-time wage ratio for female workers in 2001 was 51 percent..$^{5}$ Hereafter, the term "part-time workers" denotes both part-time and casual workers.

Although the part-time/full-time wage gap is one source of the discreteness between the two options, a more important source is probably the socalled 1.03 million yen ceiling. The Japanese tax and Social Security system, as well as the fringe benefit policies of employers, creates an environment in which married women who are dependents of their husbands have a strong

\footnotetext{
${ }^{4}$ During the same period, the number of female regular workers in the same age range changed from 7.5 to 8.9 million.

${ }^{5}$ An extensive literature on part-time jobs in Japan provides evidence of these issues; see, e.g., Houseman and Osawa (1998, 2003), Abe (2003), Gaston and Kishi (2007).
} 
incentive to restrict their earnings to less than 1.03 million yen (for recent evidence on this, see, e.g., Nagase and Nawata 2005; Akabayashi 2006; Sakata and McKenzie 2006; Abe 2009).

As a result, the annual earnings of married women are quite different depending on their employment status. Figure 1 shows the earnings distributions for full-time and part-time working women from the ESS in 2007. Part-time earnings are heavily concentrated around 1 million yen, whereas full-time earnings show no such a concentration. Earnings are higher for full-time than for part-time workers; in the ESS data used in Figure 1, the average earnings of female full-time employees are 3.3 million yen, whereas those of female part-time employees are 1.0 million. Furthermore, 93 percent of female part-time employees have earnings of less than 1.5 million yen, whereas 56 percent of female regular employees earn less than this amount. These are the main features of the discreteness in the two employment choices for women in Japan.

\subsection{Participation in full-time and part-time work by region}

To understand the features of regional variations in women's participation, I use the data from the ESS for 2007. The ESS is a household survey and the region-based statistics reported here are based on the place of residence 
(not on place of work). ${ }^{6}$

I compare the participation patterns for the four prefectures in the Tokyo Metropolitan Area: Saitama, Chiba, Tokyo, and Kanagawa. Tokyo prefecture includes the Tokyo CBD; the other three prefectures are generally suburban, although they do contain some large cities such as Saitama (in Saitama prefecture), Yokohama and Kawasaki (in Kanagawa prefecture).

In the following discussion, three measures of participation are used: the employment-to-population ratio (E-P ratio), the regular employment ratio, and the part-time employment ratio. The regular employment ratio is the number of regular employees divided by the population, for which regular employees include regular wage and salary earners, as well as executives of private corporations. The part-time employment ratio is the number of parttime and casual employees divided by the population.

The three measures are plotted against age for married women (Figure 2.A-2.C) and the regular employment ratio for married men is plotted against age (Figure 2.D), using microdata from the ESS. ${ }^{7}$ The data show several interesting patterns. First, the E-P ratio for women below age 35 is higher in Tokyo than in the three other suburban prefectures. This ratio is similar in all four prefectures after age 35. The types of female employment observed

\footnotetext{
${ }^{6}$ The ESS is conducted every 5 years by the Ministry of Internal Affairs and Communications of Japan. In 2007, the survey was conducted for adults in about 450,000 households; the size of the original sample was approximately 1 million persons aged 15 and over. The ESS data do not contain information on the location of the employment.

${ }^{7} \mathrm{I}$ omit the E-P ratio and the part-time employment ratio for married men because regional variations in the E-P ratio are smaller than those in the regular employment ratio and because the part-time employment ratio is low.
} 
in the four regions are quite different: regular employment is more common in Tokyo, whereas part-time employment is more common in the other three prefectures, independent of age. Second, over 80 percent of married men work as regular full-time employees, while less than 30 percent of married women work under such a status (Figures 2.B and 2.D). Finally, the regular employment ratio for men does not differ much across the four prefectures, although it is slightly lower in Tokyo than elsewhere. Overall, the regional differences in women's employment are clearly greater. ${ }^{8}$ It is natural to expect that these significant differences are caused by endogenous choice of residential location. Housing prices are higher in Tokyo and full-time employees earn much more than part-time employees. On the other hand, work schedules are less flexible for full-time jobs. High earnings by full-time working wives may be used to finance the high cost of housing close to the CBD. Households in which the wife does not work full time will locate farther from the CBD to spend less on housing.

\subsection{Educational composition and labor supply choices across prefectures}

Most large-scale datasets for Japanese workers do not contain information on both wage and place of residence, so it is difficult to directly test the hypothesis in the previous subsection. In this subsection, I therefore use

\footnotetext{
${ }^{8}$ More generally, it is known that women's participation in the labor market, especially with respect to regular full-time work, has significant regional variations within Japan (Takeishi 2007; Abe et al. 2008). Regional variations are small for men.
} 
education as a proxy for wage levels. It is well known that education is highly correlated with full-time wages. I first look at the proportion of educated people among residents, and then consider the proportion of educated workers among residents. ${ }^{9}$

Figure 3 shows the proportion of people with more than a university education (16 years or more) among residents in the four prefectures by age group. Among both men and women of all age groups, the proportion of highly educated persons ("power" individuals in the terminology of Costa and Kahn (2000) and Compton and Pollak (2007)) is highest in Tokyo, followed by Kanagawa, Chiba, and Saitama. These data support the notion that high-wage earners tend to live closer to the Tokyo CBD.

The educational distribution does not show whether labor supply is related to residential choice because the population considered includes both workers and non-workers. ${ }^{10}$ To see the distribution of "power workers," the proportion of those with more than a university degree and working (power working men and women) among residents is plotted in Figure 4. For both men and women, the proportion of power workers is highest in Tokyo. The pattern in Figure 4 basically mirrors the educational distribution (Figure 3), so it can be concluded that labor supply choices do not have a large impact

\footnotetext{
${ }^{9}$ Costa and Kahn (2000) define "power couples" as couples in which both spouses have more than a college degree. The available data do not allow me to investigate the combination of educational attainment of husband and wife. In this paper, "power" men and women are those who have at least a university degree, and "power working" men and women are those who have at least a university degree and work.

${ }^{10}$ In Japan, the labor force participation rate of highly educated women is not much higher than that of less educated women.
} 
on the geographical distribution of power working men and women; the effect of education is more significant.

\subsection{Housing prices, educational composition, and la- bor supply}

More evidence on educational attainment and labor supply choices by residents is provided by aggregate data from the 2000 Census of Japan. Census data are available at the municipal level; here, I focus on cities in the Tokyo prefecture. ${ }^{11}$ The Census data on educational attainment and labor supply can be matched with housing price data.

I estimate regressions relating the proportion of power working men and women to housing prices. The dependent variable is the proportion of power working men or women divided by the population. In defining the number of power working men and women, two types of workers are considered: one includes all types of employment, and the other is restricted to wage and salary earners. The independent variables are the log of mean land price and age dummies. Data for the mean land prices (per $m^{2}$ ) at the municipal level are obtained from the Public Notice of Land Prices (Ministry of Land, Infrastructure, Transport and Tourism of Japan) in 2000. Results are shown in Table 1. Land prices have a positive impact on the proportion of power working men and women: a 10 percent increase in price is associated with a

\footnotetext{
${ }^{11}$ The aggregate municipal data are available only for municipalities with a population of more than 0.5 million. There are 8 such municipalities in Tokyo prefecture.
} 
1-2 percent increase in the dependent variable. The coefficients are greater for men than for women. ${ }^{12}$

I also run regressions in which the dependent variable is the labor force participation rate and the independent variables are the log housing price and age dummies. The results are shown in Table 2. Among men and highly educated women, housing prices do not affect participation. Therefore, their labor supply choices do not differ across regions, which is consistent with the observation that the distribution of power working men and women is similar to the distribution of power men and women. Among women with a senior high school education, those who live in areas with high housing prices are more likely to participate in the labor market.

\footnotetext{
${ }^{12}$ There are several reasons for why this elasticity is higher for men than for women. First, there is a large gender wage gap among full-time workers. Even for power-working couples, earnings for the wife may be lower than those for the husband. Furthermore, male earnings are likely to have a greater dispersion than female earnings, even among power-workers. Given these factors, it is quite possible that housing prices and male earnings have stronger correlations than housing prices and female earnings. Second, the published Census data used in Tables 1 and 2 are not disaggregated over marital status so the sample for each gender includes both married and unmarried persons; it is possible that elasticity values differ across marital status. Finally, causality should not be inferred, as this pattern of the distribution of power working men and women is consistent with several other explanations. For example, highly educated people prefer to live in areas where school quality is high, and school quality and housing prices are positively correlated.
} 


\section{Model}

\subsection{Basic model}

Consider a household with two adult members, a husband and a wife. The family utility is defined as $U\left(l_{h}, l_{w}, C\right)$, where $l_{h}$ is the husband's leisure time, $l_{w}$ is the wife's leisure time, and $C$ is the value of consumption other than housing. In the rest of this paper, the first derivative of $U($.$) with respect$ to spouse $j$ 's leisure is denoted as $U_{j} \quad(j=h, w)$, and the first derivative with respect to $C$ is denoted as $U_{C}$. The second derivatives are denoted similarly $\left(U_{C w}, U_{w h}\right.$, etc.). Let $W_{h}$ represent the husband's hourly wage rate, and let $E_{h}$ represent his earnings. The model has a monocentric structure with a single CBD. It is assumed that the husband works in the CBD and his commuting distance $D$ is measured in hours. Let $\bar{D}$ be the maximum possible value of $D$ : thus, $D \in[0, \bar{D}]$.

The wife's employment choice is either full-time work, part-time work, or no work. Full-time work requires the wife to work more than $\theta$ hours. All full-time jobs are located in the CBD, so the commuting distance for any full-time job is $D$. The wife's hourly wage rate when she works full time is $W_{F}$. Part-time jobs are available at zero commuting distance, for which the wife's hourly wage rate is $W_{P}$. These assumptions are made because they are broadly consistent with empirical facts. They are also consistent with the patterns predicted by some urban economics models such as Wheeler (2001) or Andersson et al. (2007) that predict high-paying (more productive) jobs 
are likely to be located in the CBD.

It is assumed that hours of work are chosen as a continuous variable for both spouses, so the earnings function for the wife (the function that relates her working hours, $h_{w}$, to her earnings, $\left.E_{w}\right)$ can be modeled as:

$$
E_{w}\left(h_{w}\right)=\left\{\begin{array}{ll}
W_{P} h_{w} & \text { if } h_{w} \leq \theta \\
W_{F} h_{w} & \text { if } h_{w}>\theta
\end{array} .\right.
$$

Note that there is a "jump" in the earnings function at point $\theta$. This is natural in the context of the Japanese labor market, where the hourly wage rate of female full-time employees is approximately 50 percent higher than that of female part-time employees.

The time endowment for both husband and wife is $\bar{L}$ and their time constraints give

$$
\begin{gathered}
l_{h}=\bar{L}-h_{h}-D, \\
l_{w}=\bar{L}-h_{w}-I\left(h_{w}>\theta\right) \cdot D,
\end{gathered}
$$

where $h_{j}$ is the working hours of spouse $j, D$ is commuting time to the CBD, and $I($.$) is an indicator function that takes value 1$ if the relation inside the parentheses is true and zero otherwise. For simplicity, I assume that all housing units are of the same size and the incomes of the husband and wife are pooled. 
There are four possible solutions to the optimization problem described above: (1) the wife does not work $\left(h_{w}=0\right)$; (2) the wife works part time with fewer than $\theta$ hours $\left(0<h_{w}<\theta\right)$; (3) the wife works exactly $\theta$ hours as a part-time worker $\left(h_{w}=\theta\right)$; or $(4)$ the wife works full time $\left(h_{w}>\theta\right)$. When necessary, I use the following subscripts to denote the four states: $N$ for nowork, $I$ for "interior" part-time work fewer than $\theta$ hours $\left(0<h_{w}<\theta\right), T$ for part-time work at the threshold, and $F$ for full-time work. Among these four, the first three $(N, I$, and $T)$ are collectively designated as "part-time work," because "no work" and "threshold" are at the boundaries of the budget set and form corner solutions in the maximization problem for part-time work.

To derive the optimal location and labor supply choice, two sub-problems (the part-time and full-time sub-problems) are defined, and the bid-rent function for housing is derived for each. ${ }^{13}$ The bid-rent function of the part-time sub-problem is derived by solving the following problem:

$$
\underset{h_{h}, h_{w}, C}{\operatorname{Max}} W_{h} h_{h}+W_{P} h_{w}-C
$$

subject to

$$
\begin{gathered}
U\left(\bar{L}-h_{h}-D, \bar{L}-h_{w}, C\right)=u \\
0 \leq h_{w} \leq \theta
\end{gathered}
$$

where $u$ is the utility level of the household. The maximand of this problem

\footnotetext{
${ }^{13}$ The derivation in this section follows that of Fujita (1989).
} 
gives the bid-rent function for the part-time sub-problem, denoted $\psi^{P}(D, u)$. Likewise, the bid-rent function for the full-time sub-problem is derived by solving the following:

$$
\underset{h_{h}, h_{w}, C}{\operatorname{Max}} W_{h} h_{h}+W_{F} h_{w}-C
$$

subject to

$$
\begin{gathered}
U\left(\bar{L}-h_{h}-D, \bar{L}-h_{w}-D, C\right)=u, \\
h_{w} \geq \theta .
\end{gathered}
$$

The maximand of this problem gives the bid-rent function for the full-time sub-problem, denoted $\psi^{F}(D, u){ }^{14}$

Let $\tilde{C}\left(l_{h}, l_{w}, u\right)$ represent the consumption level that achieves utility level $u$ when the husband's leisure time is $l_{h}$ and the wife's is $l_{w}$. The first-order condition with respect to $h_{h}$ is the same for the two sub-problems, and is expressed as:

$$
W_{h}+\frac{\partial \tilde{C}(.)}{\partial l_{h}}=0
$$

The first-order condition with respect to $h_{w}$ in the full-time sub-problem is:

$$
W_{F}+\frac{\partial \tilde{C}(.)}{\partial l_{w}} \leq 0,
$$

\footnotetext{
${ }^{14}$ In the entire problem, the choice of $h_{w}=\theta$ is included in the part-time and not the full-time status. However, to make the full-time sub-problem well-defined (i.e., to make the opportunity set a closed set), $h_{w}=\theta$ is included in the opportunity set for the full-time sub-problem.
} 
for which the inequality holds when $h_{w}=\theta$.

The first-order condition with respect to $h_{w}$ in the part-time sub-problem is as follows:

$$
\left\{\begin{array}{lll}
W_{P}+\frac{\partial \tilde{C}\left(l_{h}, \bar{L}, u\right)}{\partial l_{w}}<0, & \text { if } h_{w}=0 & {[\mathrm{~N}]} \\
W_{P}+\frac{\partial \tilde{C}\left(l_{h}, \bar{L}-h_{w}, u\right)}{\partial l_{w}}=0, & \text { if } 0<h_{w}<\theta & {[\mathrm{I}]} \\
W_{P}+\frac{\partial \tilde{C}\left(l_{h}, \bar{L}-\theta, u\right)}{\partial l_{w}}>0, & \text { if } h_{w}=\theta & {[\mathrm{T}]}
\end{array}\right.
$$

where the letter in square brackets indicates one of the four states.

The following two conditions are met at the corner solution of $h_{w}=\theta$ :

$$
\begin{gathered}
W_{P}+\frac{\partial \tilde{C}\left(l_{h}, \bar{L}-\theta, u\right)}{\partial l_{w}}>0, \\
W_{F}+\frac{\partial \tilde{C}\left(l_{h}, \bar{L}-\theta-D, u\right)}{\partial l_{w}}<0 .
\end{gathered}
$$

The "discreteness" in the labor market is represented by this corner solution, which is the unique feature of this model. A wife's full-time work requires $D$ hours of commuting time, in addition to the hours spent at her job. Suppose the wife changes her employment status from part time to full time and increases her working hours by $\Delta h_{w}$ (from less than $\theta$ to over $\theta$ ). Then her leisure time decrease by $D+\Delta h_{w}$. $D$ is essentially the "fixed cost of full-time work," measured in hours. Unless $D=0$, there will be a range of $W_{P}$ and $W_{F}$ for which the wife's working hours are set to $\theta$ (part-time work) and do not increase even if $W_{P}$ rises (the wage elasticity of working 
hours is zero). At this corner solution, $-\partial \tilde{C}\left(l_{h}, \bar{L}-\theta, u\right) / \partial l_{w}<W_{P}<W_{F} \leq$ $-\partial \tilde{C}\left(l_{h}, \bar{L}-\theta-D, u\right) / \partial l_{w}$ holds. The wife works as many hours as possible while remaining part-time; she would like to work more than $\theta$ hours but commuting prevents her from pursuing full-time employment opportunities.

The derivative of the bid-rent function is the time cost of commuting, implying

$$
\begin{gathered}
\frac{\partial \psi^{P}}{\partial D}=-W_{h}, \quad \text { if } h_{w} \leq \theta \\
\frac{\partial \psi^{F}}{\partial D}=-\left(W_{h}+W_{F}\right) . \quad \text { otherwise }
\end{gathered}
$$

This is the familiar Alonso-Mills-Muth (AMM) condition. ${ }^{15}$ The transportation cost per hour is the opportunity cost of working and is equal to the hourly wage rate of full-time workers who commute to the CBD.

Assumption 1. Let $\Delta C\left(l_{h}, u\right)=\tilde{C}\left(l_{h}, \bar{L}-\theta-\bar{D}, u\right)-\tilde{C}\left(l_{h}, \bar{L}-\theta, u\right)$, where $l_{h}>0$. Then, for some households, $\left(W_{F}-W_{P}\right) \theta<\Delta C\left(l_{h}, u\right)$ for all $l_{h}>0$ and $u$.

To understand the implication of Assumption 1, suppose a household is located at $\bar{D} . \Delta C($.$) is the compensation necessary for the wife to work \theta$ hours as a full-time worker (commute $\bar{D}$ hours), and to keep the household equally well-off when she has part-time status and work $\theta$ hours. Assumption 1 says that for some households, the part-time/full-time wage gap is not large enough to compensate for the wife's commute of $\bar{D}$ hours for any possible values of $l_{h}$ and $u$.

\footnotetext{
${ }^{15}$ Alonso (1964), Mills (1967), and Muth (1969).
} 
Proposition 1. For all households,

$$
\psi^{P}(0, u)<\psi^{F}(0, u)
$$

For households for which Assumption 1 holds,

$$
\psi^{P}(\bar{D}, u)>\psi^{F}(\bar{D}, u)
$$

The bid-rent function for a household is

$$
\psi(D, u)=\max \left(\psi^{P}(D, u), \psi^{F}(D, u)\right)
$$

Proof. When $D=0$, the maximization problem for deriving the bid-rent functions for part-time and full-time status differ only in the level of the wife's wage (whether it is $W_{P}$ or $W_{F}$ ). Since $W_{F}>W_{P}$, it is obvious that $\psi^{P}(0, u)<\psi^{F}(0, u)$.

The bid-rent functions at location $\bar{D}$, for the full-time and part-time cases are as follows:

$$
\begin{gathered}
\psi^{F}(\bar{D}, u)=W_{h}\left(\bar{L}-l_{h}^{F}-\bar{D}\right)+W_{F} h_{w}^{F}-\tilde{C}\left(l_{h}^{F}, \bar{L}-h_{w}^{F}-\bar{D}, u\right), \\
\psi^{P}(\bar{D}, u)=W_{h}\left(\bar{L}-l_{h}^{P}-\bar{D}\right)+W_{P} h_{w}^{P}-\tilde{C}\left(l_{h}^{P}, \bar{L}-h_{w}^{P}, u\right),
\end{gathered}
$$

where $l_{h}^{k}(k=F, P)$ represents the husband's optimal leisure time in the $k$-th sub-problem. Since $h_{w}^{P}$ is chosen optimally, $\psi^{P}(\bar{D}, u)$ is higher than when $h_{w}^{P}$ 
is forced to $\theta$ in the RHS of Eq. (10) and thus:

$$
\psi^{P}(\bar{D}, u) \geq W_{h}\left(\bar{L}-l_{h}^{P}-\bar{D}\right)+W_{P} \theta-\tilde{C}\left(l_{h}^{P}, \bar{L}-\theta, u\right) .
$$

Using Eq. (11),

$$
\begin{aligned}
& \psi^{P}(\bar{D}, u)-\psi^{F}(\bar{D}, u) \\
& \geq W_{h}\left(l_{h}^{F}-l_{h}^{P}\right)+\left[\left(W_{P} \theta-W_{F} h_{w}^{F}\right)+\tilde{C}\left(l_{h}^{F}, \bar{L}-h_{w}^{F}-\bar{D}, u\right)-\tilde{C}\left(l_{h}^{P}, \bar{L}-\theta, u\right)\right] \\
& =\left(W_{P} \theta-W_{F} h_{w}^{F}\right)+\tilde{C}\left(l_{h}^{P}, \bar{L}-h_{w}^{F}-\bar{D}, u\right)-\tilde{C}\left(l_{h}^{P}, \bar{L}-\theta, u\right) .
\end{aligned}
$$

The last equality follows because

$$
\tilde{C}\left(l_{h}^{F}, \bar{L}-h_{w}^{F}-\bar{D}, u\right)-\tilde{C}\left(l_{h}^{P}, \bar{L}-h_{w}^{F}-\bar{D}, u\right)=\frac{\partial \tilde{C}(.)}{\partial l_{h}}\left(l_{h}^{F}-l_{h}^{P}\right),
$$

and $W_{h}+\partial \tilde{C}(.) / \partial l_{h}=0$.

Let $\Delta h_{w}=h_{w}^{F}-\theta \geq 0$. Then the last expression of Eq. (12) becomes

$$
W_{P} \theta-W_{F}\left(\theta+\Delta h_{w}\right)+\tilde{C}\left(l_{h}^{P}, \bar{L}-\left(\theta+\Delta h_{w}\right)-\bar{D}, u\right)-\tilde{C}\left(l_{h}^{P}, \bar{L}-\theta, u\right)
$$

Because $W_{F}=-\partial \tilde{C} / \partial l_{w}$, the following relationship holds:

$$
-W_{F} \Delta h_{w}+\tilde{C}\left(l_{h}^{P}, \bar{L}-\left(\theta+\Delta h_{w}\right)-\bar{D}, u\right)-\tilde{C}\left(l_{h}^{P}, \bar{L}-\theta-\bar{D}, u\right)=0
$$


Using Eq.(14), Eq. (13) becomes $\left(W_{P}-W_{F}\right) \theta+\Delta C\left(l_{h}^{P}, u\right)$. Assumption 1 implies this is positive. Then $\psi^{P}(\bar{D}, u)>\psi^{F}(\bar{D}, u)$ follows.

The maximum of $\psi^{P}(D, u)$ and $\psi^{F}(D, u), \psi(D, u)$, gives the bid-rent function for a household when the wife has options to work either full time or part time.

For households for which Assumption 1 holds, $\psi^{P}(\bar{D}, u)>\psi^{F}(\bar{D}, u)$ and $\psi^{P}(0, u)<\psi^{F}(0, u)$, and therefore, $\psi^{P}($.$) and \psi^{F}($.$) intersect once. { }^{16}$ Whereas $\psi^{P}(0, u)<\psi^{F}(0, u)$ is true for all households, $\psi^{P}(\bar{D}, u)>\psi^{F}(\bar{D}, u)$ requires an assumption. However, if $\psi^{P}(\bar{D}, u) \leq \psi^{F}(\bar{D}, u)$ for all, the wife works part time in no households. Since part-time work has become increasingly common in Japan in recent decades, it is natural to expect that this type of assumption holds. ${ }^{17}$

To facilitate the following discussion, two types of reservation wage are introduced.

Definition 1 (Reservation wage for part-time work). The wife's reservation wage for part-time work, $w_{P}^{*}$, satisfies the following condition:

$$
w_{P}^{*}\left(h_{h}, D, u\right)=-\frac{\partial \tilde{C}}{\partial l_{w}}\left(\bar{L}-h_{h}-D, \bar{L}, u\right) .
$$

\footnotetext{
${ }^{16}$ Since the bid-rent gradient is constant in this model, they do not intersect more than once.

${ }^{17}$ The feature whereby the overall bid-rent function is derived as the maximum of the bid-rent curves for two separate problems is similar to the model of LeRoy and Sonstelie (1983), in which bid-rent curves are derived for different transportation modes and the mode that achieves the highest bid-rent value is chosen.
} 
The reservation wage for part-time work (measured in consumption goods) is similar to the standard reservation wage concept determining whether an individual works or not.

Definition 2 (Reservation wage for full-time work). The wife's reservation wage for full-time work, $w_{F}^{*}$ is

$$
w_{F}^{*}\left(h_{h}, D, u\right)=-\frac{\partial \tilde{C}}{\partial l_{w}}\left(\bar{L}-h_{h}-D, \bar{L}-\theta-D, u\right)
$$

The four modes of work are illustrated in Figure 5 for the utility function $U\left(l_{h}, l_{w}, C\right)=u^{h}\left(l_{h}\right)+u^{w}\left(l_{w}\right)+v(C)$. The horizontal axis represents the wife's leisure time $\left(l_{w}\right)$, and the vertical axis measures the marginal utility of her leisure $\left(\partial u^{w} / \partial l_{w}\right)$. I make the following simplifying assumptions on the shape of the utility function.

Assumption 2. The utility function, $U$, is concave, and is separable between $l_{h}$ and $C$ and between $l_{w}$ and $C$, so that $U_{j C}=0 \quad(j=h, w)$. Assume further that $U_{w h} \leq 0$.

The assumption that $U_{w h} \leq 0$ is likely to hold if household responsibilities are shared by both spouses. With Assumption 2, the following proposition gives an interesting property of the above model.

Proposition 2. Under Assumption 2,

$$
\frac{d w_{F}^{*}}{d D}>0
$$


Proof. By the definition of the reservation wage for the wife's full-time work and by the relation satisfied on the indifference surface,

$$
\begin{aligned}
w_{F}^{*}\left(h_{h}, D, u\right) & \\
= & -\frac{\partial \tilde{C}(.)}{\partial l_{w}} \\
& =\frac{U_{w}\left(\bar{L}-h_{h}-D, \bar{L}-h_{w}^{F}-D, \tilde{C}\left(\bar{L}-h_{h}-D, \bar{L}-h_{w}^{F}-D, u\right)\right)}{U_{C}\left(\bar{L}-h_{h}-D, \bar{L}-h_{w}^{F}-D, \tilde{C}\left(\bar{L}-h_{h}-D, \bar{L}-h_{w}^{F}-D, u\right)\right)} .
\end{aligned}
$$

Differentiating Eq. (15) with respect to $D$ and using $U_{j C}=0 \quad(j=h, w), \mathrm{I}$ obtain

$$
\begin{array}{r}
\frac{\partial}{\partial D}\left(-\frac{\partial \tilde{C}}{\partial l_{w}}\right) \\
=\frac{\left(-U_{w h}-U_{w w}\right) U_{C}+U_{C C}\left(\tilde{C}_{h}+\tilde{C}_{w}\right) U_{w}}{U_{C}^{2}},
\end{array}
$$

where $\tilde{C}_{j}=\partial \tilde{C} / \partial l_{j}(<0)$. Because concavity of $U$ implies $U_{C C}<0, U_{w w}<0$, and $U_{w h} \leq 0$ by assumption, it follows that $\frac{\partial}{\partial D}\left(-\frac{\partial \tilde{C}}{\partial l_{w}}\right)>0$.

Proposition 2 says that when each spouse's leisure and consumption are separable and $U_{w h} \leq 0$, closer location to the CBD reduces the wife's reservation wage for full-time work. As a result, the likelihood that the wife works full time increases when the household is located close to the CBD, other things equal. The shorter commuting time decreases the fixed cost of full-time work for the wife. Proposition 2 implies that the wages of full-time working wives living closer to the CBD are not necessarily higher than those 
of wives living farther from the CBD. On the one hand, a household in which the wife works full time has more incentive to locate close to the CBD because of the AMM condition (e.g., Iwata and Tamada 2008). On the other hand, as shown in Proposition 2, it is easier for wives located close to the CBD for other reasons to participate in full-time work.

Once the wife participates as a full-time worker, a higher $W_{F}$ increases her full-time hours. This serves to reinforce the discrete nature of the labor market because the earnings differential between full-time working women and others widens. This point is summarized in the following proposition.

Proposition 3. Consider a change in full-time wage, $W_{F}$, in the range where the wife works full time. Then:

$$
-\frac{\partial \psi_{D}^{F}}{\partial W_{F}}>0
$$

where $\psi_{D}^{F}$ is the bid-rent gradient. If the substitution effect dominates the income effect in the wife's leisure choice,

$$
d h_{w} / d W_{F}>0
$$

Proof. When the wife works full time, the bid-rent gradient equals the summed wages of the husband and wife. $-\partial \psi_{D}^{F} / \partial W_{F}>0$ implies that $D$ decreases with a higher $W_{F}$. From the first-order condition for the choice of hours (Eq. (5)), $h_{w}+D$ increases with $W_{F}$ as long as the substitution effect dominates 
the income effect. Combining these two results, $h_{w}$ increases unambiguously with $W_{F}$.

Note that a high $W_{F}$ has two reinforcing impacts on $h_{w}$. First, a higher wage decreases the amount of leisure, as in the standard labor supply model. The second impact is to reduce $D$ by locating closer to the CBD. A lower value of $D$ allows a full-time working wife to increase $h_{w}$ further. A similar argument applies to the husband's hours, $h_{h}$.

The distribution of $W_{h}+I\left(h_{w}>\theta\right) \cdot W_{F}$ is determined by the correlation between the husband's wage and the wife's full-time wage, as well as the correlation between the husband's wage and the likelihood that the wife works full time. ${ }^{18}$ An implication is that housing units located close to the CBD are more likely to be occupied by two-earner households.

\subsection{Extensions}

The basic model above does not consider explicitly the link between household characteristics and the shape of the utility function. Observable household characteristics, such as the number of children and children's ages, are likely to be related to the shape of the utility function. The number of children, especially of young children, is likely to increase the marginal value

\footnotetext{
${ }^{18}$ Empirical studies in Japan to date have not reached a consensus regarding the sign of the correlation between the husband's wage and the wife's labor force participation. In the past this correlation was thought to be negative and some studies using recent data still find a negative correlation (e.g., Sasaki 2002; Nawata and Ii 2004). However, other studies point out the possibility that this correlation has become weaker over time, and may even have turned positive (e.g., Kohara 2008).
} 
of the wife's leisure time. Furthermore, larger household size increases the demand for space. Statistics for the Tokyo Metropolitan Area clearly show that the fertility rate in 2006 was higher in the suburban prefectures than in Tokyo: the total fertility rate was 1.02 in Tokyo and approximately 1.23 for Saitama, Chiba, and Kanagawa. ${ }^{19}$

Suppose there are two types of households, those with children and those without. The bid-rent for households with children takes higher values (for any $D$ ) than for childless households for two reasons. First, since households with children have a greater demand for space, the bid-rent per space is lower for households with children than that for childless households, other things equal. Second, in households with children, the marginal utility from the wife's leisure time is higher than otherwise, which makes the wife less likely to participate either in full-time or part-time employment. This, in turn, makes the bid-rent of households with children lower than that of childless households because the wife's earnings are lower. ${ }^{20}$ Therefore, the presence of children makes the division between the two employment options for wives more distinct than in the basic model laid out in Section 3.1. ${ }^{21}$ In the next section, a numerical example that includes two types of households is introduced. For type H, the marginal value of the wife's leisure time is relatively

\footnotetext{
${ }^{19}$ The figures are from the Long-term Population Statistics of Japan.

${ }^{20}$ Note that the wife's earnings appear in the objective functions for deriving the bid-rent curves (such as Eqs. (2) and (3)).

${ }^{21}$ Beckman (1973) points out that single persons and childless couples locate closer to the CBD whereas large families live in suburbs. In his model, the labor supply choices are not endogenous.
} 
high, whereas for type L, it is relatively low. I show that in this example the type $\mathrm{H}$ households are likely to locate farther from the CBD.

\section{Numerical examples}

This section presents two numerical examples of the model in Section 3. In the first example, the utility function is assumed to be the same for all households. In the second example, there are two types of households which differ in their marginal valuation of wife's leisure time.

The utility function is assumed to take the following form:

$$
U\left(l_{h}, l_{w}, C\right)=\alpha \ln \left(l_{h}\right)+\beta \ln \left(l_{w}\right)+C .
$$

I set $\alpha<\beta=0.6$ in the first model. In the second model, $\beta=0.55$ (type $\mathrm{L}$ ) for half of households in the population, and $\beta=0.65$ (type $\mathrm{H}$ ) for the other half.

It is assumed that the full-time wages of husbands and wives, $W_{h}$ and $W_{F}$, follow uniform distributions: $W_{h}$ has a uniform distribution over the interval $[1,4]$, and $W_{F}$ has a uniform distribution over the interval $[0.5,1.5]$. Note that the mean full-time wage is higher for males than for females, and that the variance of full-time wage is larger for males than for females. It is assumed that the wife's part-time wage, $W_{P}$, is correlated with $W_{F}$ as 
follows:

$$
W_{P}=\left\{\begin{array}{lc}
0.75 * W_{F} & \text { if } W_{F} \leq W_{F}^{25 t h} \\
0.7 * W_{F} & \text { if } W_{F}^{25 t h}<W_{F} \leq W_{F}^{\text {med }} \\
0.7 * W_{F}^{\text {med }} & \text { if } W_{F}>W_{F}^{\text {med }}
\end{array} .\right.
$$

For wives whose full-time wages are lower than the 25th percentile of the full-time wage distribution, the wage gap between full-time and part-time jobs is 25 percent. For wives whose full-time wages are between the 25th percentile and the median, this gap is 30 percent. For wives with full-time wages above the median, the part-time wage is 70 percent of the median full-time wage. These assumptions reflect the empirical facts that the parttime/full-time wage gap for female workers is smaller for the less educated and that part-time wages do not increase much with education. ${ }^{22}$

Note that I normalize the lower bound of the husband's full-time wage to 1 . For simplicity, matching between husband and wife is assumed to be random in terms of their full-time wage levels. ${ }^{23}$ The total time endowment $\bar{L}$ is normalized to $1 ; D, \theta, h_{w}$, and $h_{h}$ are measured using this unit. For instance, if the total time endowment is 80 hours per week, a 1-hour commute each way costs 10 hours per week (assuming full-time employees work 5 days

\footnotetext{
${ }^{22}$ In equilibrium, the part-time/full-time wage ratio is lower than 0.7 , since high-wage workers are likely to work in full-time jobs, whereas the part-time wages are capped at 70 percent of the median full-time wage.

${ }^{23}$ An example with simple assortative matching between spouses is also constructed, but the results are not reported here. The properties of the solution are essentially the same.
} 
per week) so $D$ is $0.125(=10 / 80)$. The threshold $\theta$ for full-time work is set to 0.3125 (25 hours out of 80 ). A piecewise linear relationship between $-\psi_{D}$ and $D$ is assumed, as follows: ${ }^{24}$

$$
D\left(-\psi_{D}\right)= \begin{cases}-(1 / 24)\left(-\psi_{D}-1\right)+D(1) & \text { if } 1 \leq-\psi_{D}<1.3 \\ -(1 / 32)\left(-\psi_{D}-1.3\right)+D(1.3) & \text { if } 1.3 \leq-\psi_{D}<2.5 \\ -(1 / 40)\left(-\psi_{D}-2.5\right)+D(2.5) & \text { if } 2.5 \leq-\psi_{D} \leq 5.5\end{cases}
$$

where $D\left(-\psi_{D}\right)$ corresponds to the $D$ value chosen by households for which the bid-rent gradient is $\psi_{D}$. The model is solved numerically by making discrete approximations to the distributions of wages and $-\psi_{D}$.

\subsection{Single type}

In this subsection the equilibrium outcomes when all households have the same utility function are reported. The proportions of wives working part time and full time are shown in Figure 6.A. In households located closest to the CBD, all wives work full time. In other words, housing units closest to the CBD are occupied only by two-earner households with both spouses working full time. The proportion of wives working full time decreases as $D$ increases and eventually reaches zero. The proportion of wives working part time is zero for the lowest $D$ values, and increases as $D$ increases. Although the

\footnotetext{
${ }^{24}$ In a more fundamental sense, this relationship should be derived by solving for the market clearing conditions of the housing market. I instead assume that the supply of housing units at each location $D$ yields this relationship.
} 
behaviors described are extreme, they are also consistent with the empirical patterns shown in Figure 2.

The relationship between wage levels and commuting time of working wives is shown in Figure 6.B. The size of the points/circles in Figure 6.B indicates the number of wives working at that particular wage-commuting time combination. ${ }^{25}$ By construction, the commuting time for part-time workers is zero, and part-time wages have a smaller dispersion than full-time wages. As shown in Figure 6.B, in equilibrium, some full-time working wives with low wages also have low values of $D$. This is because lower values of $D$ reduce the reservation wage for full-time work (Proposition 2). Since parttime wages are less variable and the commuting time is zero for all part-time workers, the outcomes for these workers are compressed into the lower-left corner as mass points. These results are quite different from the relationship found by Iwata and Tamada (2008), who find that working wives with the highest wages live closest to the CBD. Figure 6.B shows that some full-time working wives with high wages also have high $D$ values.

\subsection{Two types}

Next, consider the case in which households differ in their utility functions. It is assumed that there are two types, $\mathrm{H}$ and L. Type $\mathrm{H}$ has a higher marginal value for the wife's leisure time than type L does. Although the decision

\footnotetext{
${ }^{25}$ For the upper-right section of the figure, the size of individual circles is very small and the distances between the circles are short, so that they are collectively seen as thick lines.
} 
to have children is not explicitly modeled in this example, in households with children the value of the wife's leisure time is likely to be higher than in childless households, and thus they are more like type $\mathrm{H}$ households. ${ }^{26}$ Below, I report the properties that are unique to the two-type case.

Figure 6.C shows that the labor supply choices of wives of type $\mathrm{H}$ and type $\mathrm{L}$ : in type $\mathrm{H}$ households, wives are less likely to engage in paid employment. Although not clear from the figure, the proportion of those who engage in regular full-time work is 14 percent for type $\mathrm{H}$ and 29 percent for type $\mathrm{L}^{27}$ In this example, the mean $D$ in equilibrium is 0.195 , and 52 percent of type $\mathrm{H}$ households reside at locations where $D$ is higher than the mean, whereas 45 percent of type L households reside at such locations. Therefore, type L households are more likely to live closer to the CBD.

Although the examples here are quite specific, in that full-time wages are assumed to follow uniform distributions and that matching between husband and wife is random, they are consistent with the empirical features of the education and housing location distributions (Figures 2 and 3).

\footnotetext{
${ }^{26}$ Households with children are likely to have a demand for more space, but that aspect is not incorporated in this example.

${ }^{27}$ Note that the vertical axis of Figure 6.C measures the proportion of those working full time conditional on the location choice. The outcomes of location choices are not evident in the figure.
} 


\section{Conclusions}

In this paper, a simple model of family labor supply and residential location choice is presented. The model incorporates an important institutional feature of the Japanese labor market: a woman's choice between full-time work and part-time work. It can explain why women's participation behaviors differ significantly in areas that are geographically close but differ in real estate prices. Women who earn high full-time wages in the CBD tend to live close to the workplace, whereas those with lower wages live in the suburbs where housing prices are lower. The model also explains that high commuting costs (or equivalently, high housing prices in locations close to the CBD) could be one of the main obstacles to women's full-time employment in the Tokyo Metropolitan Area. In Japan, full-time and part-time employment are distinct labor-supply choices for women. I argue that the housing market operates in a way to further strengthen this discrete feature in the labor market.

One notable change in the Japanese labor market over the last two decades has been an increase in female wages: from 1990 to 2000, the average hourly wage of female regular workers rose by 20.8 percent, while that of male regular workers rose by 8.7 percent (in real terms). ${ }^{28}$ The labor force participation rate of married women aged 25-54 increased from 53 percent in

\footnotetext{
${ }^{28}$ These data are derived from the Basic Survey of Wage Structure (Ministry of Health, Welfare and Labour of Japan) and CPI statistics (Ministry of Internal Affairs and Communications of Japan).
} 
1980 to 59 percent in $2000 .{ }^{29}$ An investigation of how these changes in the labor market have affected the housing market and the residential patterns is left for future research.

\section{Appendix: Evidence from the New York Metropolitan Area}

In order to examine whether the theoretical model is relevant in other metropolitan areas, the relationship between residential and employment choices are examined for the New York Metropolitan area using the 2000 US Census data. I use the Integrated Public Use Files from the US Census (IPUMS) from the year 2000 (Ruggles et al. 2010), and extract residents of the New York metropolitan area (the metropolitan area code equals 560) who are not attending school.

For the US case, there is no counterpart to the regular and part-time employment statuses that exist in Japan. Therefore, I use participation measures based on working days and hours. These are (1) the proportion of Full-Time, Full-Year (FTFY) workers who are wage-salary earners among residents, and (2) the proportion of part-time (non-FTFY) workers who are wage-salary earners among residents. FTFY workers are those who worked at least 50 weeks in the previous year and whose usual hours of work is 35

\footnotetext{
${ }^{29}$ Labour Force Survey (Statistics Bureau, Ministry of Internal Affairs and Communications of Japan).
} 
hours or more. ${ }^{30}$

It is important to note that the two definitions (based on the employment status in the workplace and on working hours) are not the same: when I apply the measures from the working hour definition to the Japanese data, the regional differences are not as pronounced as those shown in Figure 2. Furthermore, for the working hour definition, regional differences are not necessarily greater for women than for men. ${ }^{31}$

In panels A-D of Figure A1, the participation measures are plotted against age for married women residing in the central city area and those residing outside this area and for the two different education levels (at least high school diploma, and at least a Bachelor's degree). ${ }^{32}$ The feature whereby those who live closer to the CBD are more likely to work full time is clearly seen for married women with a Bachelor's degree or more. The FTFY profile for married men with a Bachelor's degree or more are shown in panel E of Figure A1. Unlike women, men living in the central city area are less likely to work FTFY.

\footnotetext{
${ }^{30}$ This definition of FTFY work is used by Devereux (2004). The restriction for wagesalary earners is made for making the sample comparable to the Japanese data in this paper.

${ }^{31}$ Possible reasons for the small regional differences for women with the working hour definition are that: (1) some part-time workers (in the Japanese definition) work many hours so that they are classified as FTFY workers even though their status at the workplace is not regular workers; (2) there are slightly more female, married regular workers who do not work FTFY in Tokyo than the suburban prefectures.

${ }^{32}$ When the data are plotted for all married women regardless of education level, the FTFY profiles for some ages are at similar levels for central city residents and others. A possible reason for this is that low-income individuals tend to reside in the city center because of transportation cost (Gleaser et al. 2008).
} 
Table A1 lists the proportion of place of work (central city area or otherwise), by the place of residence (central city area or otherwise) for married women and men with degree-level education. Among FTFY workers residing in the central city area, over 80 percent work in the central city area. Among FTFY workers residing outside of the central city area, 26 percent of female workers and 34 percent of male workers commute to the central city area. Majority (78 percent) of female part-time workers who reside outside of central city area work outside of central city. The right half of Table A1 shows the average commuting time for each group of workers defined by employment status, gender, and places of residence and work. Those who reside and work in the central city area spend 37-39 minutes for commuting (one way), while female part-time workers who work outside of the central city spend 21 minutes. FTFY workers who commute from the outside of central city to central city spend over 60 minutes. These patterns suggest that part-time jobs are available outside of central city area, allowing married women to spend less time for commuting.

\section{References}

Abe, Yukiko (2003) "Fringe Benefit Provision for Female Part-time Workers in Japan." In: Seiritsu Ogura, Toshiaki Tachibanaki, and David Wise (eds) Labor Markets and Firm Benefit Policies in Japan and the United States, The University of Chicago Press, Chicago, 339-370. 
Abe, Yukiko (2009) "The Effects of the 1.03 million yen Ceiling in a Dynamic Labor Supply Model." Contemporary Economic Policy 27(2): 147-163. Abe, Yukiko (2010) "The Equal Employment Opportunity Law and labor force behavior of women in Japan." Journal of The Japanese and International Economies, forthcoming, DOI: 10.1016/j.jjie.2010.06.003.

Abe, Yukiko and Aiko Tanaka (2008) "The Full-time/Part-time Wage Gap in Japan and the Role of the Regional Minimum Wage: 1990-2001." Japanese Journal of Labour Studies (in Japanese).

Abe, Yukiko, Shiori Kondo, and Kunie Mori (2008) "On regional differences of women's labor supply: An analysis of the regular employment ratios using aggregate data." ["Jyosei shugyo no chiiki-sa ni kansuru kousatu -Shukei data wo motiita seiki-koyo shugyoritsu no bunseki"], Japanese Journal of Research on Household Economics 80, 64-74 (in Japanese). Akabayashi, Hideo (2006) "The Labor Supply of Married Women and Spousal Tax Deduction in Japan- A Structural Estimation." Review of Economics of the Household 4(4): 349-378.

Alonso, William (1964) Location and Land Use, Harvard University Press, Cambridge.

Andersson, Fredrik, Simon Burgess, and Julia I. Lane (2007). "Cities, Matching and the Productivity Gains of Agglomeration." Journal of Urban Economics 61(1): 112-128.

Beckman, Martin (1973) "Equilibrium models of residential land use." Regional and Urban Economics 3(4): 361-368. 
Compton, Janice, and Robert D. Pollak (2007) "Why are power couples increasingly concentrated in large metropolitan areas?" Journal of Labor Economics 25(3): 475-512.

Costa, Dora L. and Matthew E. Kahn (2000) "Power couples: Changes in the locational choice of the college educated, 1940-1990." Quarterly Journal of Economics 115(4): 1287-1315.

Del Boca, Daniela, and Annamaria Lusardi (2003) "Credit market constraints and labor market decisions." Labour Economics 10, 681-703.

Devereux, Paul, J. (2004) "Changes in Relative Wages and Family Labor Supply." Journal of Human Resources 39:3, 696-722.

Fortin, Nicole (1995) "Allocation inflexibilities, female labor supply and housing assets accumulation: are women working to pay the mortgage?" Journal of Labor Economics 13, 524-557.

Fujita, Masahisa (1989) Urban Economic Theory: Land Use and City Size, Cambridge University Press, Cambridge.

Gaston, Noel, and Tomoko Kishi (2007) "Part-time workers doing full-time work in Japan." Journal of the Japanese and International Economies $21,435-454$.

Glaeser, Edward L., Matthew E. Kahn, and Jordan Rappaport (2008) "Why do the poor live in cities? The role of public transportation?" Journal of Urban Economics 63, 1-24.

Houseman, Susan, and Machiko Osawa (1998) "What is the nature of parttime work in the United States and Japan?" in: O'Reilly, Jacqueline and 
Fagan, Colette eds: Part-time prospects: An international comparison of part-time work in Europe, North America and the Pacific Rim, pp. $232-251$.

Houseman, Susan, and Machiko Osawa (2003) "The Growth of Nonstandard Employment in Japan and the United States: Comparison of Causes and Consequences." In: Houseman, S., and M. Osawa, eds, Nonstandard Work in Developed Economies, W.E. Upjohn Institute for Employment Research, Kalamazoo, Michigan, pp. 175-214.

Iwata, Shinichiro and Keiko Tamada (2008) "The backward-bending commute time of married women under household responsibility." CIRJE Discussion Paper Series F-582, University of Tokyo.

Kohara, Miki (2008) "Is the Full-Time Housewife a Symbol of a Wealthy Family?" Japanese Economy 34(4): 25-56.

LeRoy, Stephen, and Jon Sonstelie (1983). "Paradise Lost and Regained: Transportation Innovation, Income, and Residential Location." Journal of Urban Economics 13(1): 67-89.

Mills, Edwin (1967) "An aggregative model of resource allocation in a metropolitan area." American Economic Review 57, 197-210.

Ministry of Health, Welfare, and Labour, Long-term Population Statistics, http://www.mhlw.go.jp/toukei/saikin/hw/jinkou/suii06/brth4.html, access date 2009/12/5.

Ministry of Land, Infrastructure, Transport and Tourism, Public Notice of Land Prices in 2000 
http://tochi.mlit.go.jp/chika/kouji/20000324/20000324u2.html, access date $2008 / 11 / 5$.

Mok, Diana (2007) "Do two-earner households base their choice of residential location on both incomes?" Urban Studies 44, 723-750.

Muth, Richard (1969) Cities and Housing, Univ. of Chicago Press, Chicago.

Nagase, N., and K. Nawata (2005) "Changes in Taxes and Social Security System on Part-Time Labor Supply. (Part no zeisei, shakai-hoken seido no henkou to roudou kyoukyu heno eikyo.)" [in Japanese]. Mimeo, Ochanomizu University.

Nawata, Kazumitsu and Masako Ii (2004) "Estimation of the labor participation and wage equation model of Japanese married women by the simultaneous maximum likelihood method." Journal of the Japanese and International Economies 18: 301-15.

Steven Ruggles, J. Trent Alexander, Katie Genadek, Ronald Goeken, Matthew B. Schroeder, and Matthew Sobek (2010) Integrated Public Use Microdata Series: Version 5.0 [Machine-readable database]. Minneapolis: University of Minnesota.

Sakanishi, Akiko (2007) "Gender differences in travel-to-work area and commuting behavior." Journal of Applied Regional Science No.12 pp.95-108 (in Japanese).

Sakanishi, Akiko (2008) "Commuting time of female workers: A panel data analysis." mimeo (in Japanese).

Sakata, K., and C. R McKenzie (2006) "The Impact of the Tax Reform 
in 2004 on the Female Labour Supply in Japan." Mimeo, Ritsumeikan University.

Sasaki, Masaru (2002) "The Causal Effect of Family Structure on Labor Force Participation among Japanese Married Women." Journal of Human Resources 37(2): 429-40.

Takeishi, Emiko (2007) Transitions of women's career and inter-regional comparison ["Macro data de miru jyosei no career no hensen to chiiki kan hikaku"] Shogai gakushu to career design 4, Hosei University, 19-34 (in Japanese).

Ueda, Atsuko (2007) “A Dynamic Decision Model of Marriage, Childbearing, and Labor Force Participation of Women in Japan." Japanese Economic Review 58(4): 443-65.

Wheeler, Christopher H. (2001). "Search, Sorting, and Urban Agglomeration." Journal of Labor Economics 19(4): 879-899.

Yoshikawa, Hiroshi, and Fumio Ohtake (1989) "An analysis of female labor supply, housing demand and the saving rate in Japan." European Economic Review 2, 999-1023. 
Table 1: Proportion of power men and women and housing price

\begin{tabular}{|c|c|c|c|c|}
\hline & $(1)$ & (2) & (3) & (4) \\
\hline & \multicolumn{2}{|c|}{$\begin{array}{l}\text { Education=University or more \& } \\
\text { working }\end{array}$} & \multicolumn{2}{|c|}{$\begin{array}{l}\text { Education=University or more \& } \\
\text { wage-salary earner }\end{array}$} \\
\hline & Men & Women & Men & Women \\
\hline Log(land price) & $\begin{array}{l}0.188^{* *} \\
(0.038)\end{array}$ & $\begin{array}{l}0.101 \text { ** } \\
(0.018)\end{array}$ & $\begin{array}{l}0.1633^{\star \star} \\
(0.034)\end{array}$ & $\begin{array}{l}0.088 \text { ** } \\
(0.016)\end{array}$ \\
\hline Dummy for Age 30-34 & $\begin{array}{r}0.031 \\
(0.043)\end{array}$ & $\begin{array}{l}-0.066 * * \\
(0.020)\end{array}$ & $\begin{array}{r}0.021 \\
(0.039)\end{array}$ & $\begin{array}{l}-0.071 * * \\
(0.018)\end{array}$ \\
\hline Dummy for Age 35-39 & $\begin{array}{r}0.082 \\
(0.044)\end{array}$ & $\begin{array}{l}-0.089 * * \\
(0.021)\end{array}$ & $\begin{array}{r}0.059 \\
(0.040)\end{array}$ & $\begin{array}{l}-0.100 \\
(0.019)\end{array}$ \\
\hline Dummy for Age $40-44$ & $\begin{array}{l}0.112 \\
(0.047)\end{array}$ & $\begin{array}{l}-0.079 \\
(0.022)\end{array}$ & $\begin{array}{r}0.073 \\
(0.043)\end{array}$ & $\begin{array}{l}-0.097 * * \\
(0.020)\end{array}$ \\
\hline Dummy for Age 45-49 & $\begin{array}{r}0.046 \\
(0.047)\end{array}$ & $\begin{array}{l}-0.108 \text { ** } \\
(0.022)\end{array}$ & $\begin{array}{r}0.004 \\
(0.042)\end{array}$ & $\begin{array}{l}-0.122 * * \\
(0.020)\end{array}$ \\
\hline Dummy for Age 50-54 & $\begin{array}{r}-0.008 \\
(0.044)\end{array}$ & $\begin{array}{l}-0.141 \\
(0.020)\end{array}$ & $\begin{array}{r}-0.050 \\
(0.040)\end{array}$ & $\begin{array}{l}-0.1511^{* *} \\
(0.019)\end{array}$ \\
\hline Dummy for Age 55-59 & $\begin{array}{r}-0.086 \\
(0.046)\end{array}$ & $\begin{array}{l}-0.176 \text { ** } \\
(0.021)\end{array}$ & $\begin{array}{l}-0.121 * * \\
(0.042)\end{array}$ & $\begin{array}{l}-0.181 \text { ** } \\
(0.019)\end{array}$ \\
\hline Observations & 56 & 56 & 56 & 56 \\
\hline R-squared & 0.49 & 0.72 & 0.51 & 0.76 \\
\hline
\end{tabular}

Notes: Robust standard errors in parentheses.

The base group for age group is age 25-29.

A constant is included in each regression, but the coefficients are not shown.

${ }^{*}$ significant at the $5 \%$ level; ${ }^{* *}$ significant at the $1 \%$ level.

Source: Author's calculation from aggregate data of 2000 Census and the Public Notice of Land Prices, 2000. 
Table 2: Labor force participation rate and housing price

\begin{tabular}{|c|c|c|c|c|}
\hline & (1) & (2) & (3) & (4) \\
\hline & Women & & Men & \\
\hline & University & Senior High & University & Senior High \\
\hline \multirow{2}{*}{$\overline{\text { Log(land price) }}$} & 0.012 & 0.053 ** & -0.001 & 0.004 \\
\hline & $(0.015)$ & $(0.011)$ & $(0.001)$ & (0.002) \\
\hline Dummy for Age 30-34 & $\begin{array}{l}-0.171 \\
(0.015)\end{array}$ & $\begin{array}{c}-0.122 \\
(0.018)\end{array}$ & $\begin{array}{c}0.015 \\
(0.003)\end{array}$ & $\begin{array}{c}0.008 \text { * } \\
(0.004)\end{array}$ \\
\hline Dummy for Age 35-39 & $\begin{array}{l}-0.250 \\
(0.013)\end{array}$ & $\begin{array}{l}-0.119 \\
(0.014)\end{array}$ & $\begin{array}{c}0.019 \\
(0.003)\end{array}$ & $\begin{array}{c}0.011 \\
(0.004)\end{array}$ \\
\hline Dummy for Age 40-44 & $\begin{array}{l}-0.246 \\
(0.014)\end{array}$ & $\begin{array}{l}-0.059 \\
(0.014)\end{array}$ & $\begin{array}{c}0.020 \\
(0.003)\end{array}$ & $\begin{array}{l}0.011 \text { ** } \\
(0.003)\end{array}$ \\
\hline Dummy for Age 45-49 & $\begin{array}{l}-0.241 \\
(0.019)\end{array}$ & $\begin{array}{r}-0.028 \\
(0.015)\end{array}$ & $\begin{array}{l}0.018 \text { ** } \\
(0.003)\end{array}$ & $\begin{array}{l}0.011 \\
(0.003)\end{array}$ \\
\hline Dummy for Age 50-54 & $\begin{array}{l}-0.256 \\
(0.023)\end{array}$ & $\begin{array}{l}-0.044 \\
(0.016)\end{array}$ & $\begin{array}{l}0.014 \\
(0.003)\end{array}$ & $\begin{array}{l}0.007 \text { * } \\
(0.004)\end{array}$ \\
\hline Dummy for Age 55-59 & $\begin{array}{l}-0.331 \\
(0.023)\end{array}$ & $\begin{array}{l}-0.109 \text { ** } \\
(0.019)\end{array}$ & $\begin{array}{r}-0.002 \\
(0.003)\end{array}$ & $\begin{array}{r}-0.006 \\
(0.003)\end{array}$ \\
\hline Observations & 56 & 56 & 56 & 56 \\
\hline R-squared & 0.89 & 0.73 & 0.84 & 0.57 \\
\hline
\end{tabular}

Notes: Robust standard errors in parentheses.

The base group for age group is age 25-29.

A constant is included in each regression, but the coefficients are not shown.

* significant at the $5 \%$ level; ** significant at the $1 \%$ level.

Source: Author's calculation from aggregate data of 2000 Census and the Public Notice of Land Prices, 2000. 


\begin{tabular}{|c|c|c|c|c|c|}
\hline & \multicolumn{3}{|c|}{ Residence } & \multicolumn{2}{|l|}{ Residence } \\
\hline & Workplace & Central City & $\begin{array}{c}\text { in MA, Not Central } \\
\text { City }\end{array}$ & Central City & $\begin{array}{c}\text { in MA, Not Central } \\
\text { City }\end{array}$ \\
\hline \multirow[t]{2}{*}{ Female FTFY workers } & Central City & 86.17 & 25.91 & 37.35 & 62.31 \\
\hline & in MA, Not Central City & 5.36 & 64.37 & 43.33 & 25.73 \\
\hline Female Part-time workers & Central City & 88.44 & 15.28 & 33.17 & 53.47 \\
\hline \multirow[t]{2}{*}{ Male FTFY workers } & Central City & 84.01 & 33.74 & 39.00 & 65.56 \\
\hline & in MA, Not Central City & 9.16 & 59.40 & 47.27 & 30.99 \\
\hline
\end{tabular}

Source: Author's calculation from the IPUMS from the year 2000 (Ruggles et al. 2010).

Notes: Entries for "Proportion of workplace location conditonal on residence" do not sum up to 100 percent because there are other categories (such as outside of the metropolitan area). 
Figure 1

Earnings distributions of regular and part-time female employees

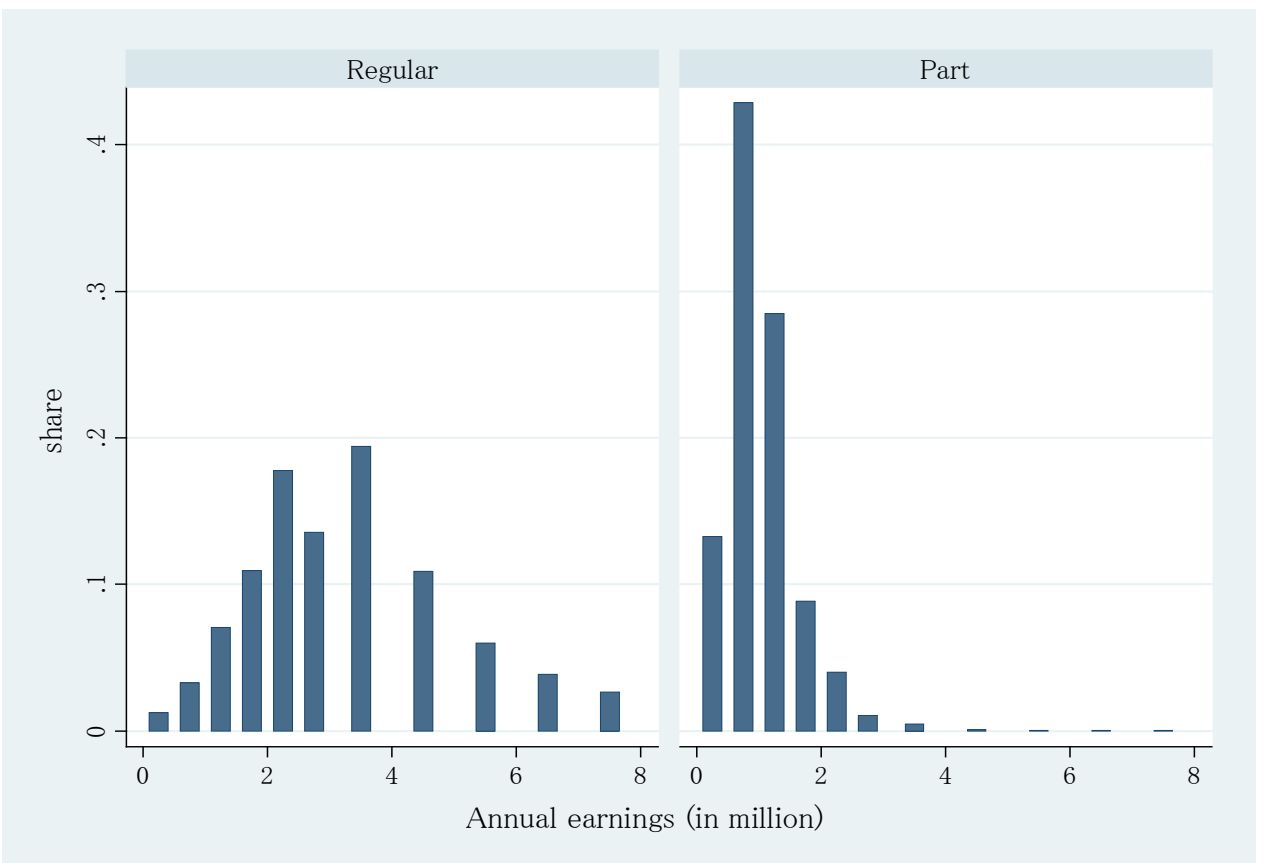

Source: Employment Status Survey 2007 (published version)

Notes: The earnings are surveyed in intervals in the ESS, and the horizontal axis of the figure corresponds to the midpoint of the earnings interval. Since the intervals are not evenly spaced, the midpoints that appear in the figure are not evenly spaced.

Data are from all regions in Japan. 
Figure 2 : Employment population ratio, regular employment ratio,

and part-time employment ratio of married women and men in

four prefectures in the Tokyo Metropolitan Area
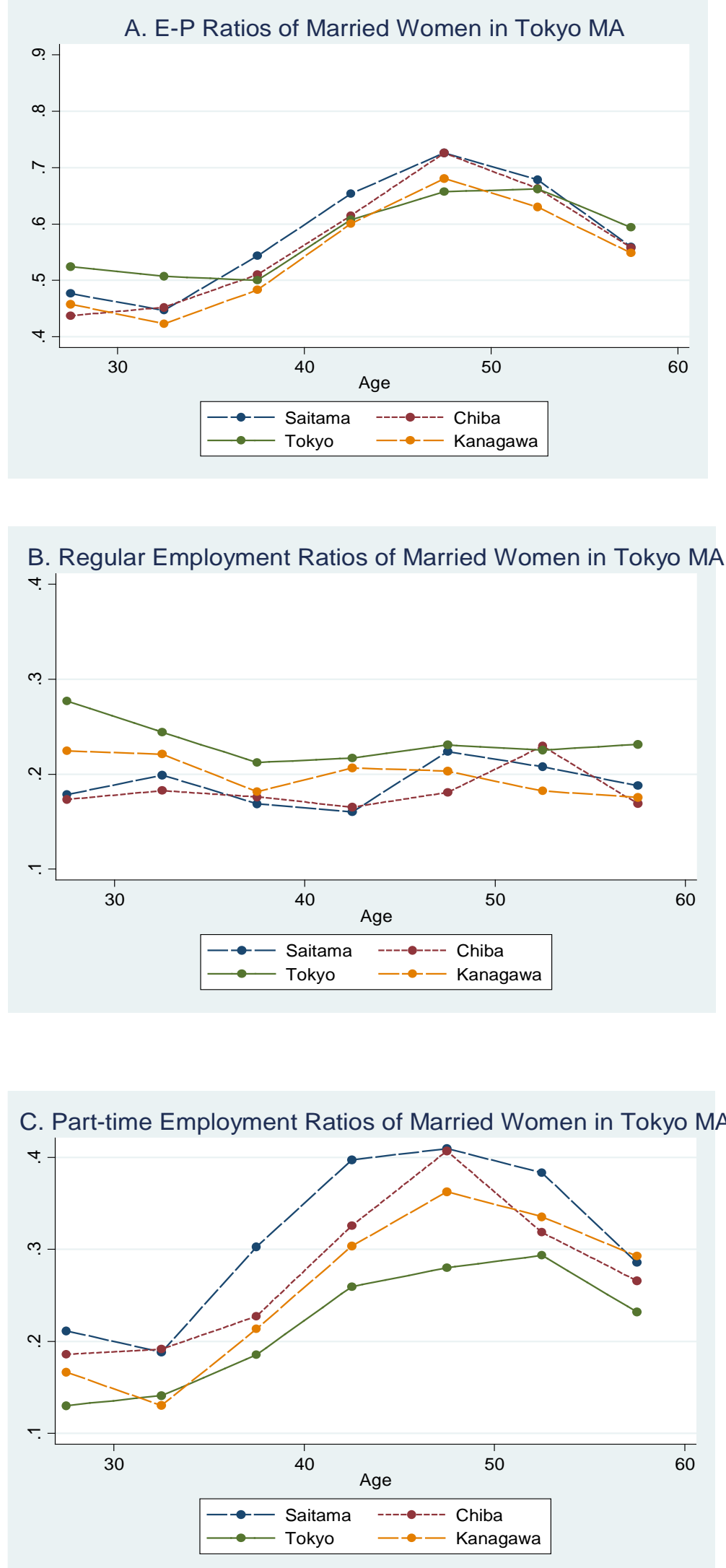
Figure 2 (continued)

D. Regular Employment Ratios of Married Men in Tokyo MA

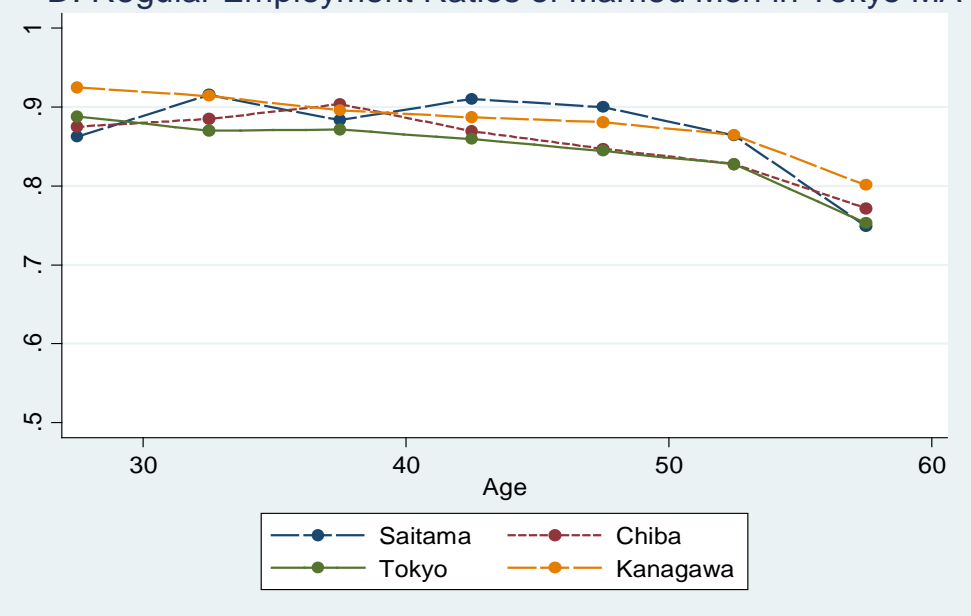

Source: Employment Status Survey 2007 
Figure 3: Share of residents with a university degree or more, by prefecture in Tokyo Metropolitan Area

Share of residents with a university degree or more by Prefecture: Men

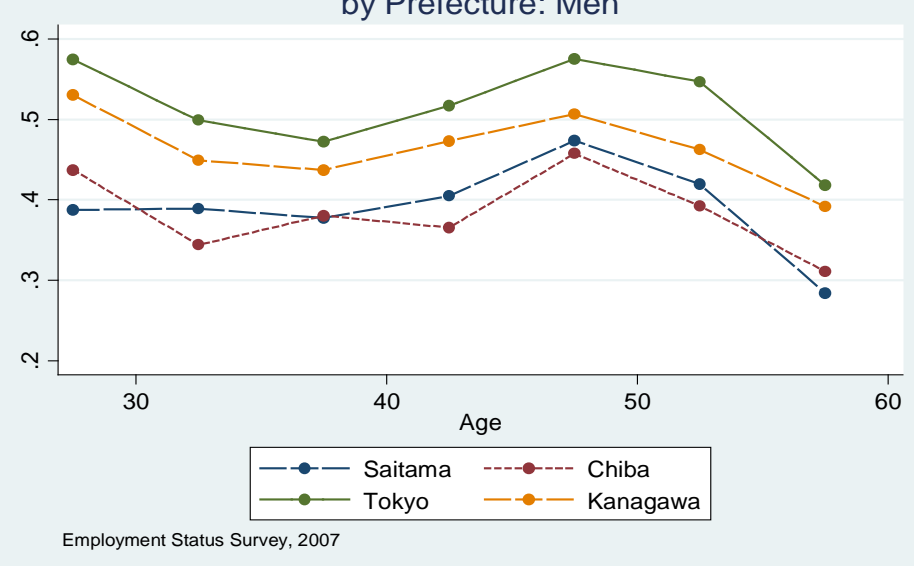

Share of residents with a university degree or more by Prefecture: Women

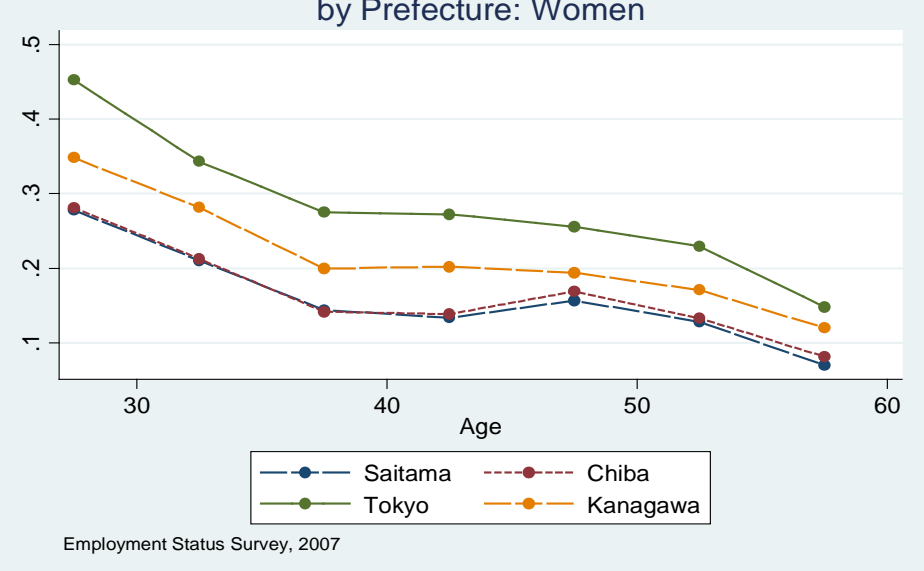


Figure 4: Share of power men \& women among residents by prefecture, Tokyo Metropolitan Area
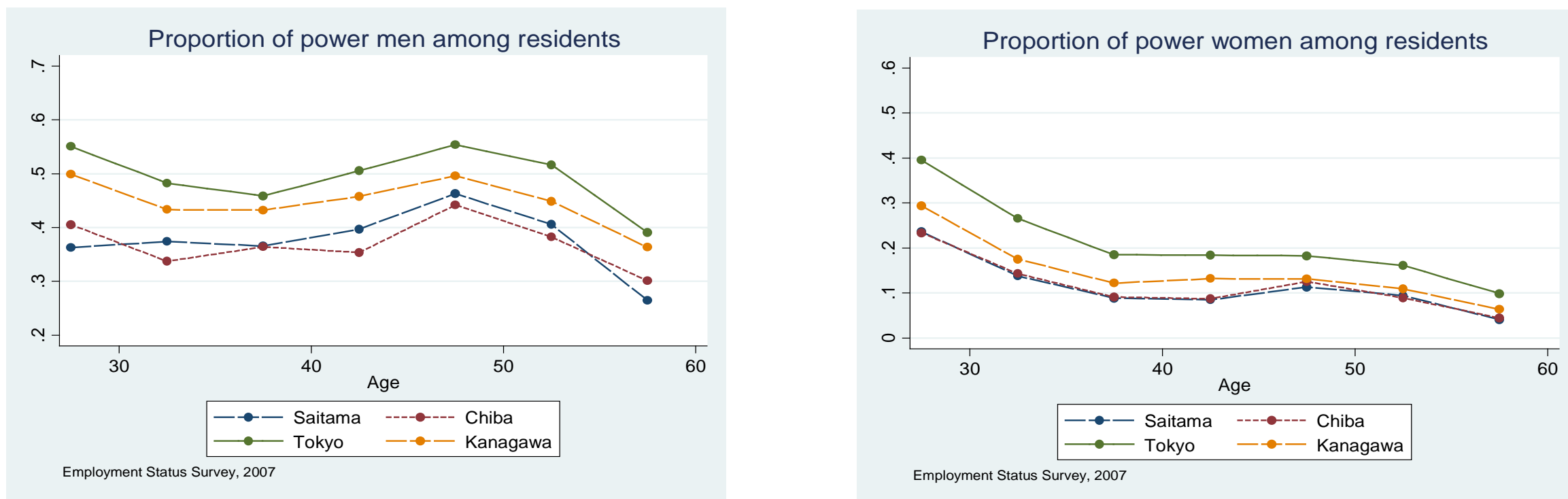


\section{Figure 5: Wife's employment choice with a separable utility function:}

$\partial u^{w}\left(l_{w}\right) / \partial l_{w}$

$$
U\left(l_{h}, l_{w}, C\right)=u^{h}\left(l_{h}\right)+u^{w}\left(l_{w}\right)+v(C)
$$

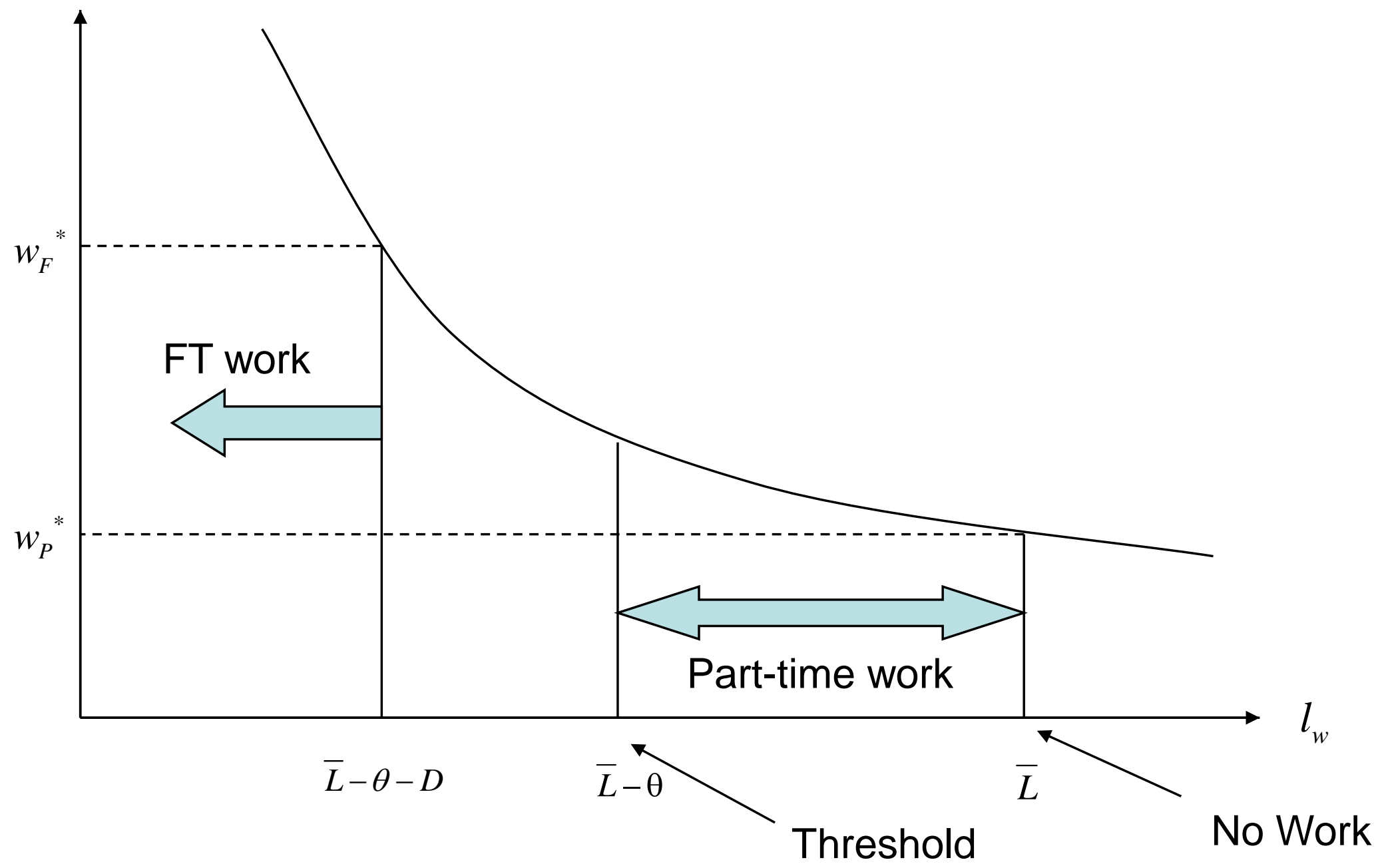


Figure 6.A. Distribution of wife's employment status and D: single type

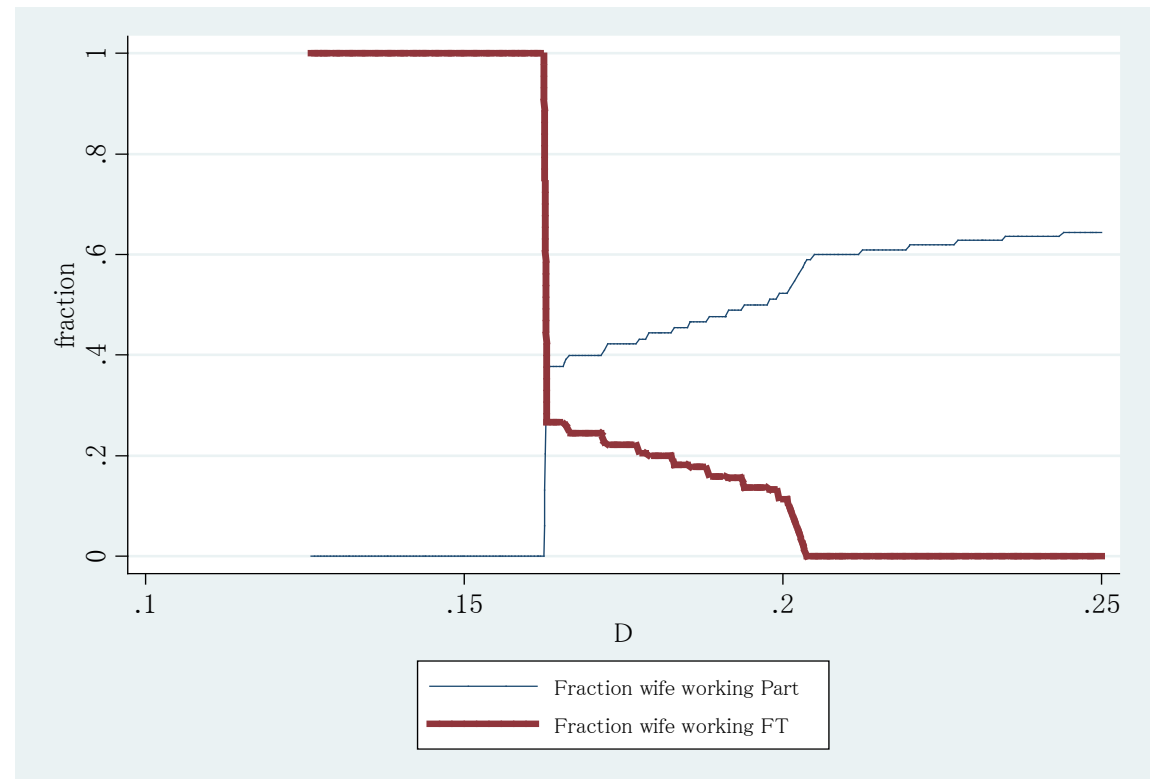

Figure 6.B. Working wives' commuting time and wage

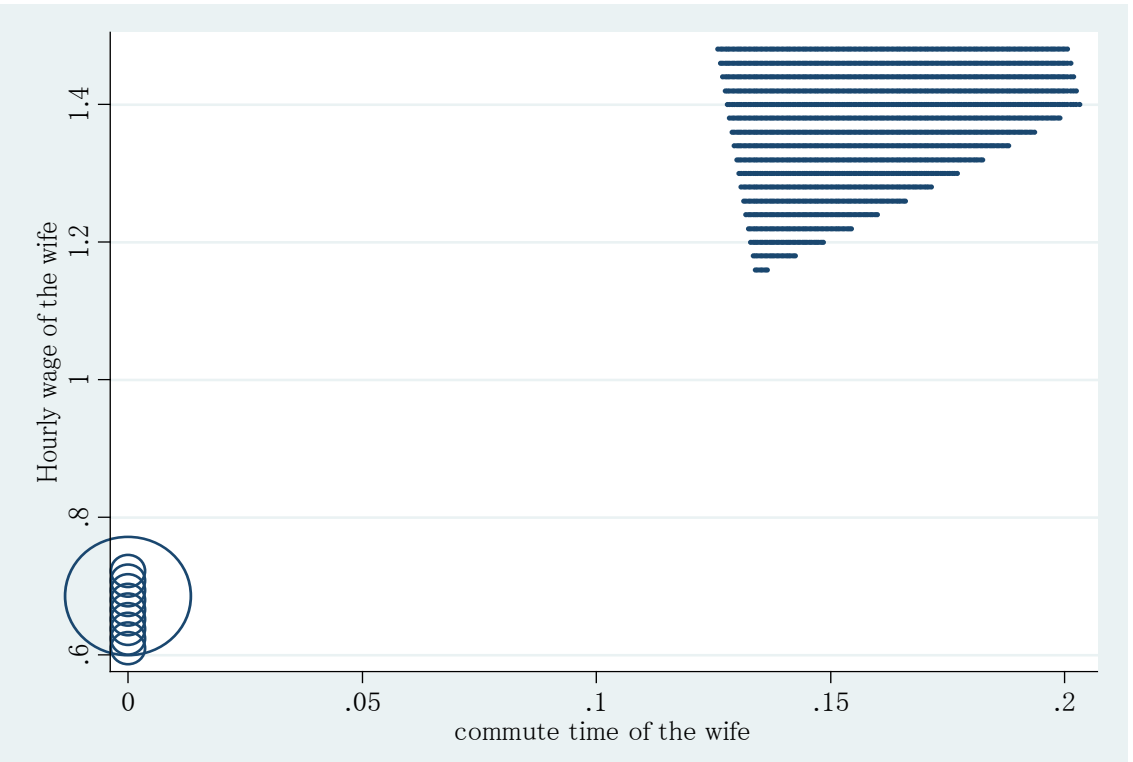

Note: Size of the circle corresponds to the number of wives with the corresponding commuting time and wage. For the upper-right section, the size of individual circles is very small and the distances between the circles are short, so that they are collectively seen like thick lines. 
Figure 6.C. Distribution of wife's employment status and D: two types

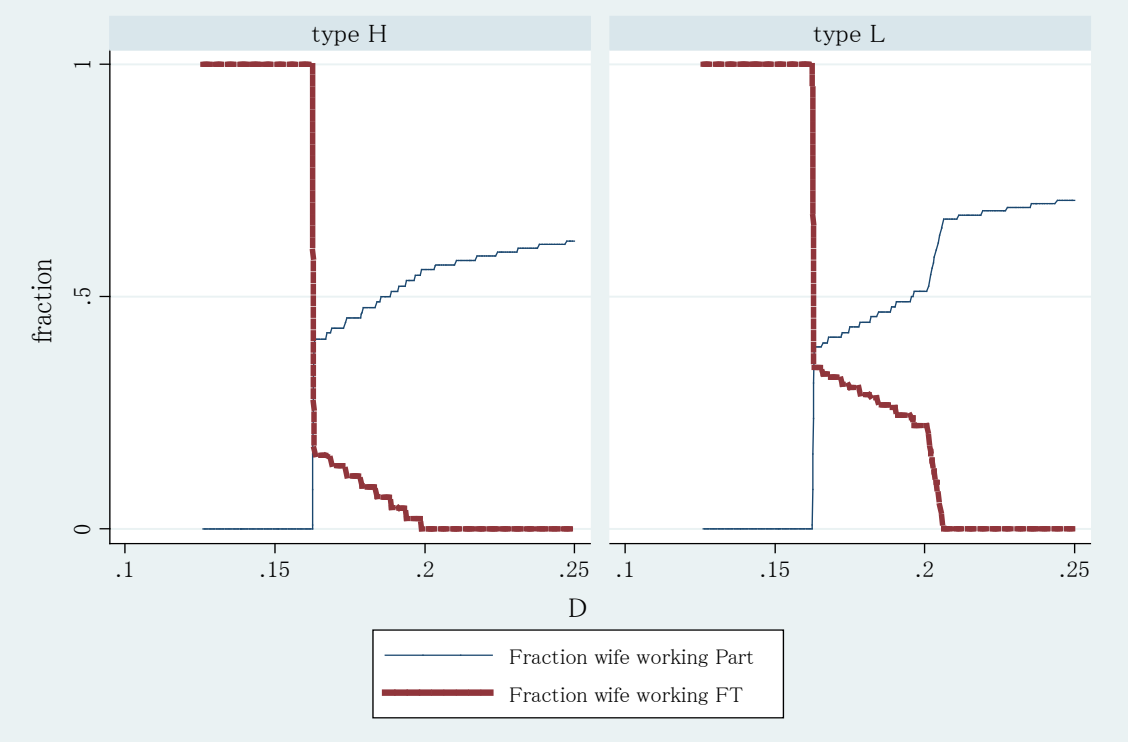


Figure A1 Labor force patterns of married women residing in the New York Metropolitan Area
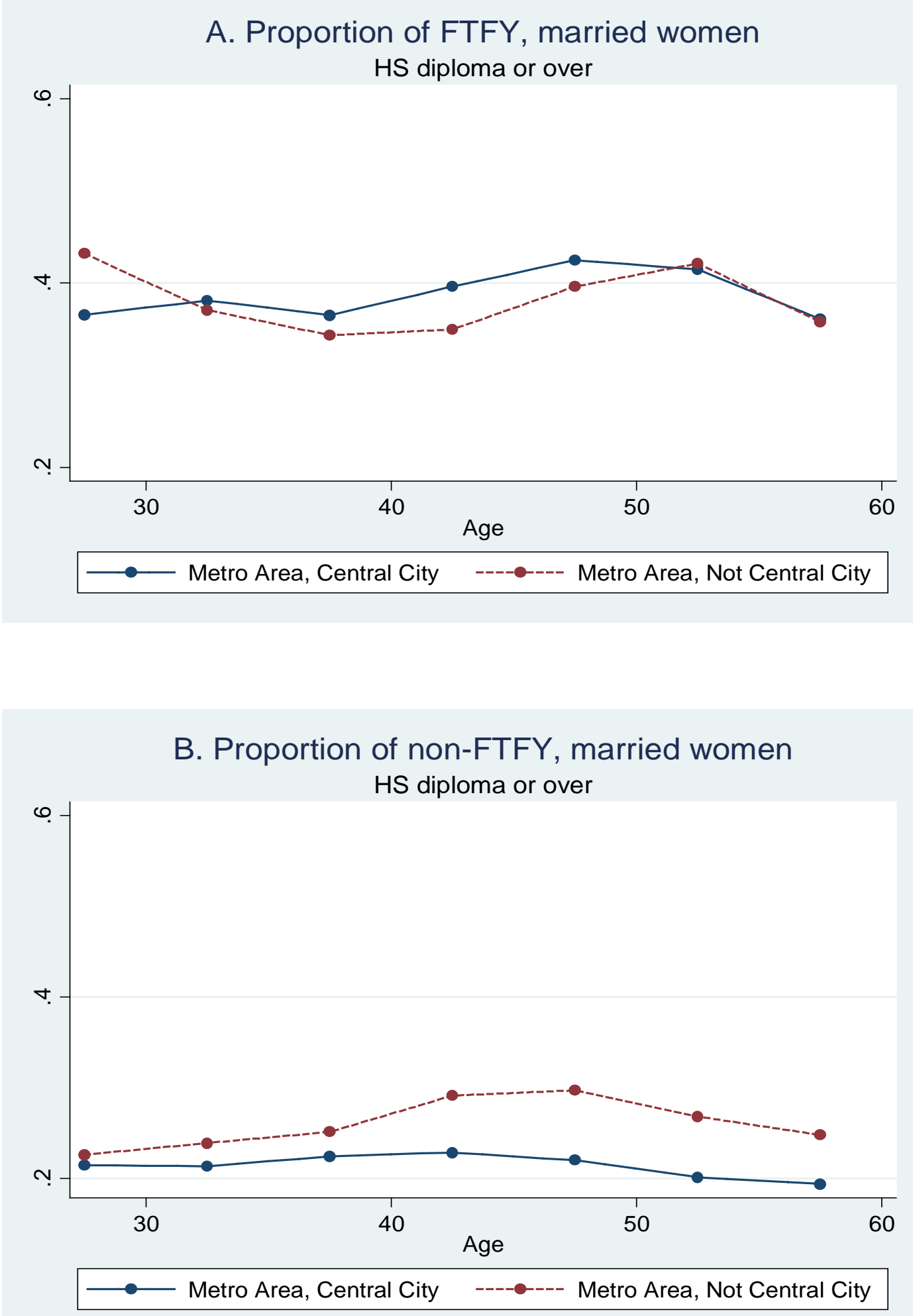
Figure A1 (continued)
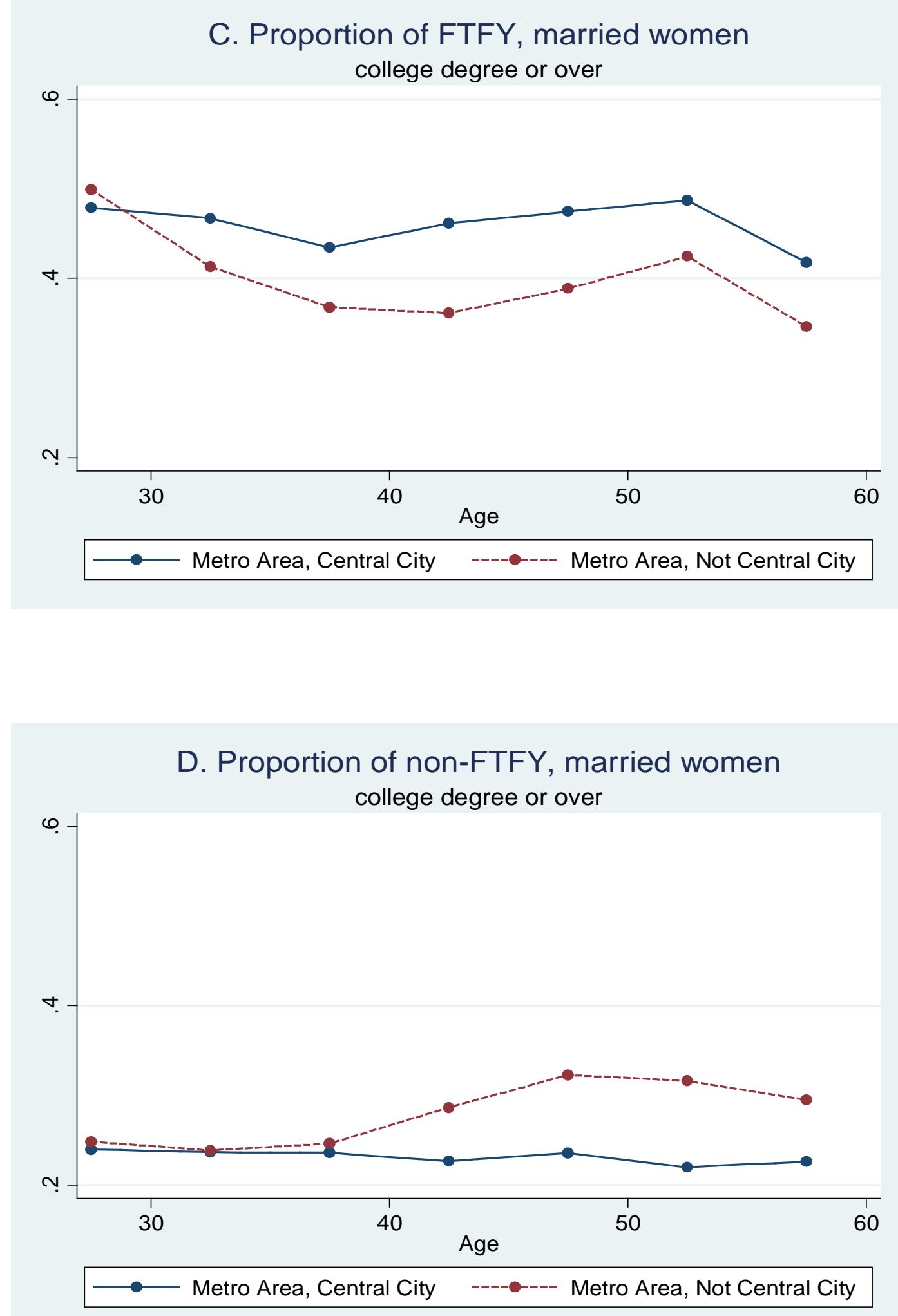
Figure A1 (continued)

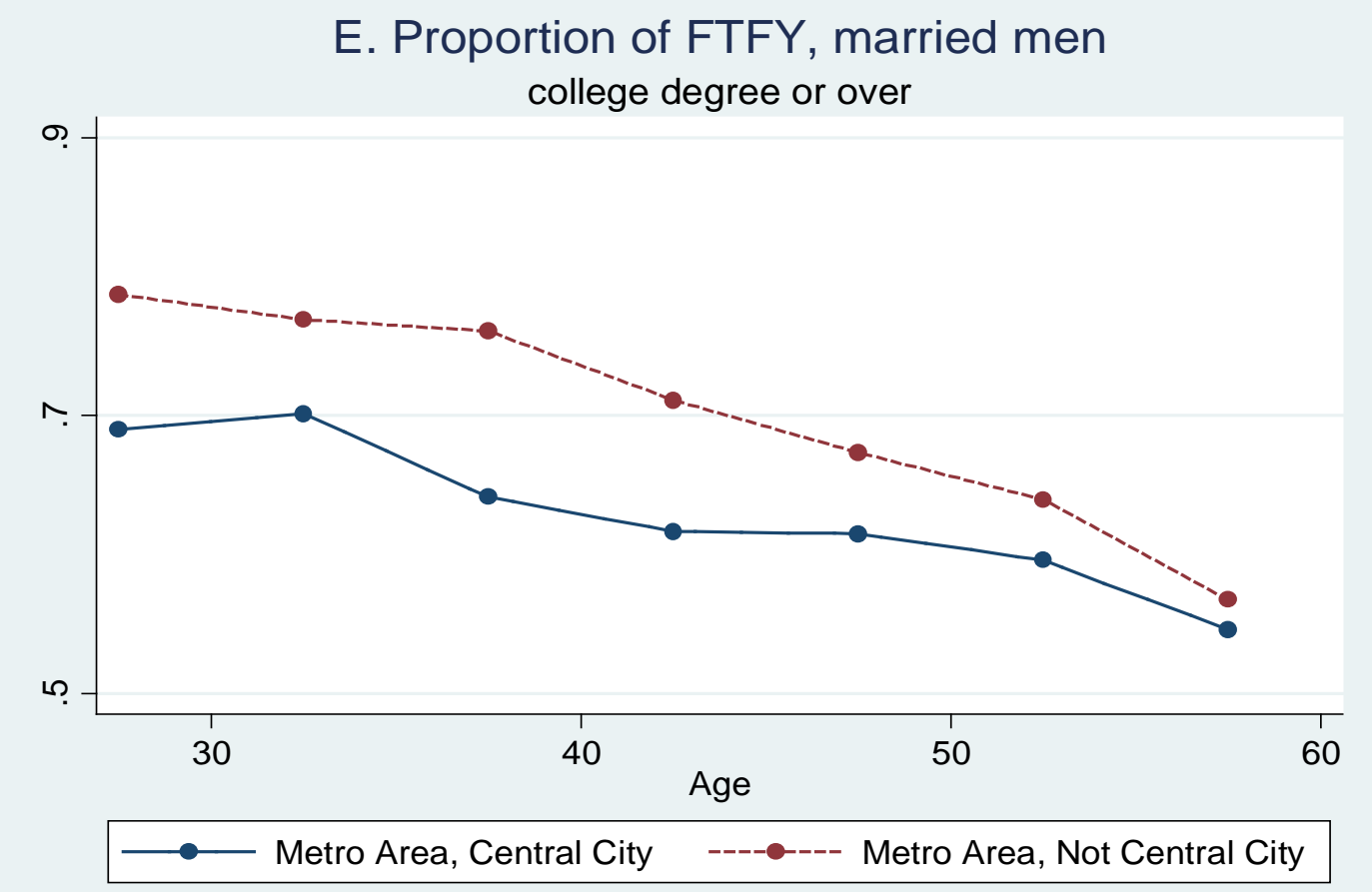

